\title{
7. The beginnings of Al's interest in VAW
}

The present chapter examines the beginnings of Al's interest in issues of violence against women, focusing on the period between 1989 and 2001 . I first explore the international level (section 7.1) and then the Swiss and the German sections in section 7.2. This chapter thus highlights the changes concerning VAW in AI's human rights policy and emphasizes the ways in which AI integrated the issue into its activities, while respecting the boundaries of its mandate. In so doing, the chapter stresses the importance of women strategizing at the international and the national levels for understanding AI's growing interest in VAW. Further, it shows the disinterest with which parts of the movement approached the intensification of AI's work on issues of VAW in the 1990s.

\subsection{The international level}

Section 7.1.1 begins by descriptively charting the gradual development of AI's policy from its essential focus on civil and political rights to the adoption of a mission recognizing the indivisibility of all human rights, including economic, social, and cultural rights. It does so by examining ICM decisions. Section 7.1.2 then highlights how the organization integrated VAW into its activities while respecting the frame of the mandate. In section 7.1.3, I emphasize the relevant internal actors. I also demonstrate that female activists' strategizing in an intersectional network initiated AI's work on women's rights and successfully influenced decision-making and implementation by lobbying sections, the IEC, and the IS. Later, section 7.1.4 shows that the integration of issues of VAW into AI's work met with officials' and activists' disinterest and reluctance, rather than with their resistance. 


\subsubsection{Policy development 1989-2001}

By focusing on the decisions made at the ICMs between 1989 and 2001, this section provides a detailed account of AI's policy development regarding $\mathrm{VAW}^{1}$ and concludes with a brief description of how the policy changes were reflected in AI's strategic plans. Between 1989 and 2001, the International Council met seven times (in 1989, 1991, 1993, 1995, 1997, 1999, and 2001). The delegates made many decisions at each ICM. ${ }^{2}$ Some of them concerned AI's work on VAW either directly or indirectly. As I show later, distinguishing between these two types allows me to accurately explain the origins of the respective ICM decision and the debates heralding its adoption. I also differentiate between these two categories because, as I have mentioned before, policy developments regarding VAW cannot be analyzed in isolation from the modification of the essential principles of Al's mandate.

By distinguishing between the two categories, figure 1 provides a graphical overview of the policy developments between 1989 and 2001 . The mandate modifications highlighted in the left rectangles of the figure indirectly concerned AI's work on VAW, as their principal target was not VAW, but AI's broader mandate. In fact, as I have already revealed, the integration of nonstate actors into Al's mandate (illustrated in the upper gray box in the right rectangle of figure 1) and the subsequent end of the mandate, with the concomitant extension to social, cultural, and economic rights (illustrated in the lower gray box in the right rectangle of figure 1) are important general policy changes that also influenced how AI dealt with issues of VAW in its activities.

At the same time, the organization directly adopted various decisions concerning its work on VAW (illustrated in the right rectangle of figure 1). ${ }^{3}$ For instance, the delegates adopted several decisions demanding an increase in AI's work on women's rights. I have labeled these decisions "Al's work on women's rights" (illustrated on the left in the right rectangle of figure 1 ). At the same

Because only the ICM can make decisions amending the mandate/the mission or the statute, analyzing ICM decisions allows us to understand policy development in general and regarding VAW in particular.

2 As an example: The 1989 ICM released 55 decisions, the 1991 ICM issued 86 decisions, the 1993 ICM and the 1995 ICM each resulted in 50 decisions, the 1997 ICM resulted in 51 decisions, the 1999 ICM resulted in 49 decisions, and the 2001 ICM resulted in 36 decisions.

3 I label these three sub-types as decisions directly concerning Al's work on VAW because their focus was only and explicitly on how Al should handle VAW in its work. 
time, the ICM explicitly decided to integrate Female Genital Mutilation (FGM) in its promotional and, later, in its oppositional work. The related decisions are labeled "a specific women's right/a specific women's rights violation" in the middle of the right rectangle in figure 1 . Further, the organization decided to broaden its approach concerning governmental inaction in cases of VAW committed by private actors and enlarged the criteria for the adoption of prisoners of conscience (labeled "women's rights in general" on the right side of the right rectangle of figure 1 ).

Figure 1: Overview of the policy development between 1989 and 2001

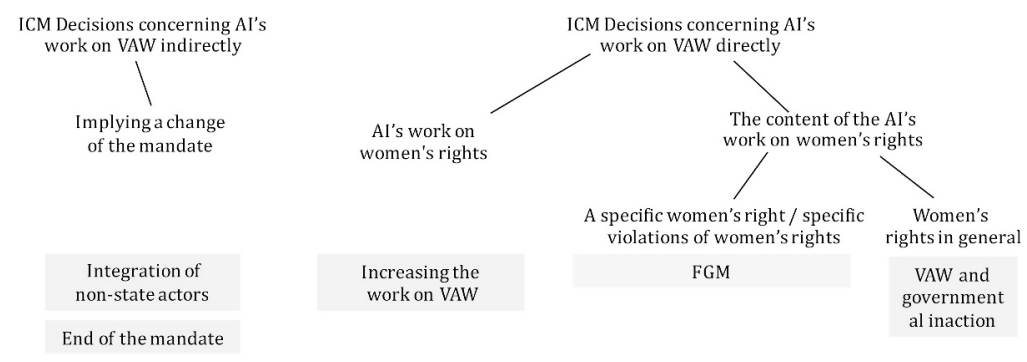

Source: my own

If we classify the summarized decisions according to the ICM during which they were adopted, it becomes evident that AI adopted most of the decisions directly concerning its work on VAW at the 1995 ICM (graph 4 and figure 2). This convergence points to the importance that the momentum gained at the fourth WCW held for the organization's growing interest in women's rights issues. As I explain in more detail later, the WCW can be considered a window of opportunity as far as the advancement of the organization's work on VAW is concerned. 
Graph 4: Decisions per ICM, 1989-2001

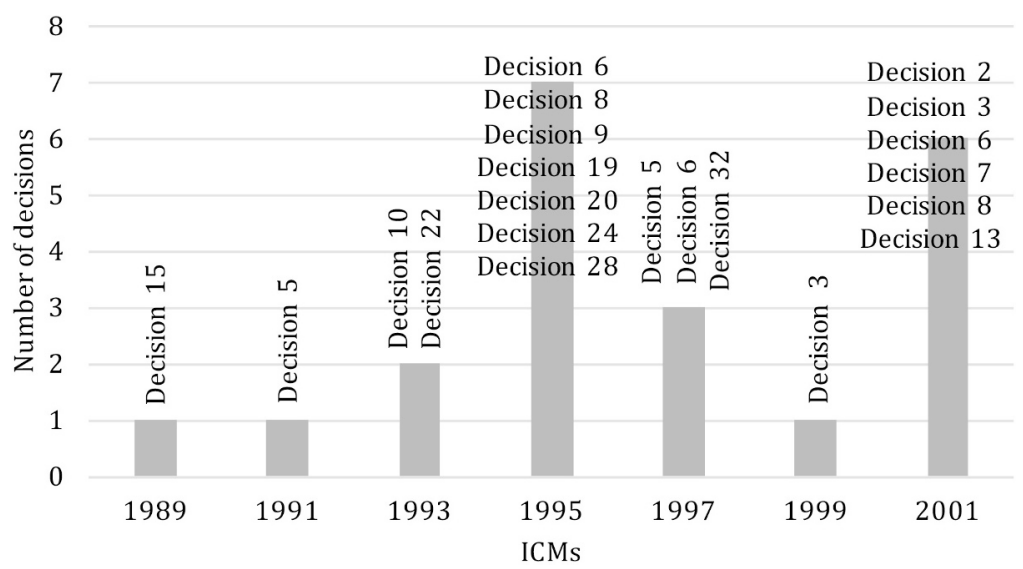

Source: my own, based on ICM reports for the years 1989, 1991, 1993, 1995, 1997, 1999, and 2001.

By distinguishing between ICM decisions directly and indirectly concerning AI's work on VAW, this paragraph provides a general overview of the development of AI's policy in this issue area between 1989 and 2001. The following sections highlight the policy developments focusing on the content of the ICM decisions adopted between 1989 and 2001. It starts with the description of the decisions indirectly concerning AI's work on VAW before describing the ICM decisions directly concerning the latter. Figure 2 shows all ICM decisions directly or indirectly concerning AI's work on VAW.

\subsubsection{ICM decisions indirectly concerning Al's work on VAW}

The following section illustrates the implications of AI's gradual mandate opening for the work on violence against women by focusing on the ICM decisions indirectly concerning this work (illustrated in the left rectangle of figure 2). In this period, the delegates to the ICM made several decisions challenging the essence of the mandate, which finally led to the adoption of a new mission in 2001. I distinguish between decisions implying a reconceptualization of the civil and political rights approach (upper gray box in the left rectangle of figure 2 ) and decisions that demand abandoning this old way of working (lower gray box in the left rectangle of figure 2). 
Figure 2: Detailed policy development between 1989 and 2001

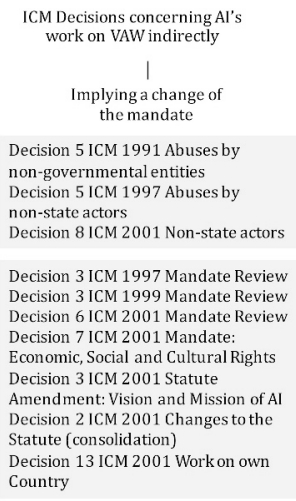

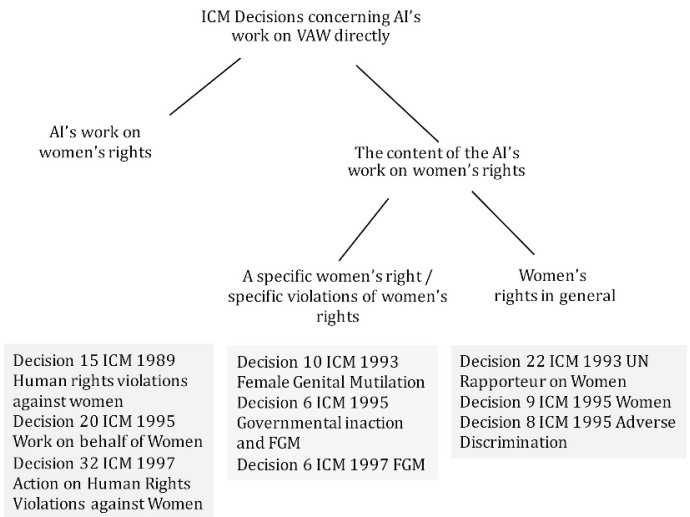

Source: my own, based on ICM reports for the years 1989, 1991, 1993, 1995, 1997, 1999, and 2001.

Until 1991, AI considered the state to be the primary violator of human rights and the organization's activities mostly targeted governments. Because of the topicality of interstate conflicts and the emergence of new patterns of human rights violations, AI included abuses committed by "political nongovernmental entities," such as arbitrary killings and hostage taking, into its mandate in 1991 (Decision 5 of the 1991 ICM). ${ }^{4}$ Hopgood states that "the implications of this [decision] were profound - it opened the way for social and economic rights, allowing AI to move its attention away from the state exclusively to take in corporations or the relations between individuals (e.g., men and women)." Nevertheless, the same decision reaffirmed "that AI should continue to regard human rights as the individual's rights in relation to governmental authority." 6

Subsequent ICM decisions continued to challenge AI's focus on civil and political rights and on the state as the primary perpetrator of human rights abuses in the following years. For example, by adopting decision 5 at the 1997 ICM, the delegates decided that: "AI will act when governments breach their

\footnotetext{
$4 \quad$ Kelleher and Bhattacharjya 2013.

5 Hopgood 2006, p.120.

6 Amnesty International: 1991 ICM Decisions.
} 
duty to ensure respect for human rights by failing to take action against abuse of human rights by private actors where that abuse would constitute a grave violation of human rights [...]." Working on cases of human rights violations where the state failed to meet its obligation to prevent the abuse was a new field of activity for AI. Conscious of the need to acquire first experiences in this particular domain, the ICM decided to do pilot projects in order to develop its future oppositional work on abuses by non-state entities. Decision 5 of the 1997 ICM called for an inclusion of the issues of women's rights into these pilot projects. ${ }^{8}$ As I detail in the next section, three out of four pilot projects finally concerned issues of women's rights, such as honor killings in Pakistan, abuses affecting women trafficked from Russia into Israel's sex industry, private security actors in Brazil, and female genital mutilation in West Africa. ${ }^{9}$ At the same time, by prohibiting the use of oppositional techniques towards non-state actors, AI dispensed with holding these actors accountable. Four years later, the delegates finally decided to use oppositional and promotional techniques towards non-state actors (Decision 8 of the 2001 ICM). This amendment was decisive for AI's effective work on VAW, as it enabled the organization to hold the perpetrators accountable.

During the same period, AI started a general discussion about its mandate. Several ICM decisions reflected this debate and preceded the ultimate decision to abandon the mandate, which was taken at the 2001 ICM (see the gray box on the lower left side in the left rectangle of figure 2). As a concrete manifestation of this final amendment, delegates expressed the concern that "the mandate is sometimes perceived as unwieldy and unfocused"10 and called for a comprehensive review of AI's mandate until the 2001 meeting at the 1997 ICM (Decision 3 of the 1997 ICM). ${ }^{11}$ Two years later, the 1999 ICM (Decision 3) stressed the importance of a mandate review again, suggesting that the IC

7 Amnesty International, International Secretariat: The Decision of the 1997 ICM, 05.01.1998, p.8-9.

Amnesty International, International Secretariat: The Decision of the 1997 ICM, 05.01.1998, p.9.

9 Amnesty International, International Secretariat: Mandate Review 1997-2001: NonState Actors, August 2000, p.6.

10 Amnesty International, International Secretariat: Inside the mandate - issue 9, November 2000 .

11 Amnesty International, International Secretariat: Inside the mandate - issue 9, November 2000 . 
should "explore whether and to what extent AI could address more effectively violations of economic, social and cultural rights."12

After a movement-wide consultation, the IEC submitted three different approaches for a first discussion: first, the "status quo" approach, which would continue to restrict AI's work to civil and political rights; second, the "new core concept" approach, which would gradually broaden the scope of AI's work to integrate some economic, social, and cultural rights; and third, the "full spectrum" approach, which would change the mandate into a mission and would enable AI to use oppositional techniques against violations of economic, social, and cultural rights. ${ }^{13}$ At the 2001 ICM, after an intensive discussion, the delegates finally agreed to go for the "full spectrum" approach and to replace the mandate with a mission. The organization thus scratched the list of specific violations of civil and political rights off its statutes and claimed to "undertake research and action focused on preventing and ending grave abuses of the rights to physical and mental integrity, freedom of conscience and expression, and freedom from discrimination, within the context of its work to promote all human rights" (Decision 2 and Decision 3 of the 2001 ICM). ${ }^{14}$ In decision 6, the IC further affirmed "the need to break down the perception that civil and political rights are more important than economic, social, and cultural rights;",15 and recognized "the consensus in the movement that AI needs to engage further with economic, social and cultural rights. ${ }^{16}$ With Decision 6, the IC further decided to increase its cooperation with other NGOs: "[...] engaging in strategic alliances with other NGOs whose expertise, information or action possibilities can usefully and effectively combine with those of AI [.... ${ }^{n 17}$ Meanwhile, decision 7 of the 2001 ICM emphasized the indi-

Amnesty International, International Secretariat: 24th International Council 1999, September 1999, p.7-8.

13 Amnesty International, International Secretariat: Inside the mandate - issue 9, November 2000 .

Decision 2 specifies that the IC decided to adopt the new Statute of Al detailed in Decision 3 (Amnesty International, International Secretariat: Report and Decisions of the 25th International Council of Amnesty International, 2001).

Amnesty International, International Secretariat: Report and Decisions of the 25 th International Council of Amnesty International, 2001, p.116.

Amnesty International, International Secretariat: Report and Decisions of the 25 th International Council of Amnesty International, 2001, p.116.

17 Amnesty International, International Secretariat: Report and Decisions of the 25th International Council of Amnesty International, 2001, p.117. 
visibility of all human rights stating that "AI may use any appropriate technique to oppose grave abuses of economic, social and cultural rights where these abuses arise from a policy of discrimination, or are abuses of the rights to freedom of conscience and expression, freedom from discrimination, or physical and mental integrity." 18

The adoption of the mission was significant for AI's work on VAW, as it allowed for the interpretation of VAW as a structural and social problem whose root causes lay in the social and economic subordination of women, and not merely as individual acts. Yet equally important for AI's concrete and effective work for the elimination of VAW was the 2001 ICM decision abandoning the WOOC rule, which prohibited sections from intervening in favor of victims of human rights abuses in their own country. This limitation had been debated repeatedly. Yet, only in 2001 did a majority of the sections' delegates finally vote for the abolition of this rule (Decision 13 of the 2001 ICM). ${ }^{19}$ This decision facilitated AI's engagement against VAW, as it enabled sections to campaign against specific women's rights violations in their own countries. It therefore enhanced the cooperation with local women's rights organization on this specific issue, which in turn was crucial for effective action.

\subsubsection{ICM decisions directly concerning Al's work on VAW}

This section demonstrates that by adopting three ICM decisions calling for an increase in AI's work on women's rights, the organization intended to strengthen its work on VAW, which falls within the mandate during the 1990 s (gray box on the bottom left in the right rectangle of figure 2). The section then emphasizes that FGM was the first women-specific human rights violation with which AI expanded its mandate (gray box in the middle of the right rectangle in figure 2 ). The section concludes by describing several ICM decisions that illustrate the organization's growing awareness of the importance of gender-specific human rights violations (gray box on the right side in the right rectangle of figure 2 ).

\footnotetext{
18 Amnesty International, International Secretariat: Report and Decisions of the 25th International Council of Amnesty International, 2001, p.119.

19 The WOOC policy was first adopted in Decision 29 of the 1979 ICM, revised in Decision 35 of the 1987 ICM, and simplified in Decision 48 of the 1995 ICM.
} 
ICM decisions calling for an increase in the work on women's rights

As mentioned before, until 1989, AI's work on violence against women was rather ephemeral and essentially limited to individual cases of female prisoners of conscience. At the 1989 ICM, the IC adopted its first decision calling for increased attention and resources for the work on human rights violations against women. In decision 15, the IC "resolved that human rights violations against women which fall within AI's mandate deserve more attention in the research of the IS and the publication activities of the IS and sections and that adequate resources be provided for that." ${ }^{20}$ In decision 15 , the IC further requested $\mathrm{AI}$ to cooperate with other NGOs and Intergovernmental Organizations (IGOs) in its actions "to seek protection and safeguards for women which give due consideration to the aspects of human rights violations that are specific to their sex." ${ }^{21}$

As I show later, because parts of the movement considered the resulting activities related to violations of women's rights insufficient, decision 20 of the 1995 ICM recalled decision 15 of the 1989 ICM and requested a clarification of AI's work on women. Further, decision 20 sought to ensure that the work for the promotion and protection of women's human rights be carried out at all levels of the organization. It also stipulated that the work on women's human rights become an integral part of AI's overall work, especially in research and publications, so that adequate personal and financial resources be provided in its support. In contrast to decision 15 (1989 ICM), decision 20 of the 1995 ICM further recommended strengthening the financial and human resources available to initiate and effectively monitor the work to end human rights violations against women, which falls within the mandate. ${ }^{22}$

Again in 1997, the IC declared itself "concerned that [...] the full potential for AI's work on women's human rights has yet to be realized,"23 and worried about providing "continued provision of support for the implementation of organizational mechanisms that will lead to the full integration of women's human rights in all areas of Amnesty International's work." ${ }^{24}$ In order to re-

\footnotetext{
20 Amnesty International, International Secretariat: Decision No. 15 ICM 1989, 1989.

21 Amnesty International, International Secretariat: Decision No. 15 ICM 1989, 1989.

22 Amnesty International, International Secretariat: 22nd International Council Meeting, 1995.

23 Amnesty International, International Secretariat: The Decision of the 1997 ICM, 05.01.1998, p.47.

24 Amnesty International, International Secretariat: The Decision of the 1997 ICM, 05.01.1998, p.47.
} 
alize the integration of women's rights into all areas of AI's work, the IC recommended conducting a comprehensive gender audit at all levels of the organization and including a focus on gender into the sections' mandate training and development sessions as well as in their strategic planning processes. ${ }^{25}$ As I highlight later, the ICM delegates refused to undergo a gender audit at the 1995 ICM, but accepted the request at the 1997 ICM.

These three ICM decisions sought to make the organization increase its work on violations of women's rights that fell within the mandate without demanding a change in the state-focused mandate. They called for sufficient personal and financial resources, and they formulated concrete recommendations on how to make women's rights an integral part of AI's overall work. As I highlight later, these decisions go back to female AI activists' and officials' movement-wide strategizing to make AI increase its work on violations of women's rights. Even though none of these decisions explicitly mentioned the issue of VAW, they directly enabled and promoted AI's activities on this front, as they demanded a sustained integration of the work on women's rights violations into AI's overall work within the frame of the mandate.

ICM decisions concerning the work on FGM

Female genital mutilation was the first women-specific human rights violation with which AI expanded its mandate. Concretely, the issue entered the decision-making process at the 1993 ICM. There, in decision 10, the IC expressed its concern about the practice of FGM, considering it as "[...] causing permanent health risks and in many cases death or major damage to [the] health [of women]." ${ }^{26}$ Decision 10 urged the IEC to include the issue in a study on governmental inaction, in order to clarify if and to what extent AI should include FGM in its promotional work and get involved in cases "where human rights abuses are inflicted by individual citizens on each other." ${ }^{27}$ Further, the decision "instructs the IEC to present recommendation on this matter to the next ICM."28

25 Amnesty International, International Secretariat: The Decision of the 1997 ICM, 05.01.1998.

26 Amnesty International, International Secretariat: The Decisions of the 1993 ICM, 30.09.1993, p.13

27 Amnesty International, International Secretariat: The Decisions of the 1993 ICM, 30.09.1993, p.14.

28 Amnesty International, International Secretariat: The Decisions of the 1993 ICM, 30.09.1993, p.14. 
After intensive debates, AI recognized the practice as "[affecting] the full enjoyment of human rights by millions of women and girls" and acknowledged that governmental inaction in cases of FGM constitutes a violation of international human rights standards. It then integrated FGM into its promotional mandate (Decision 61995 ICM). Two years later, by integrating FGM into the pilot projects on the future of Al's oppositional work against nonstate actors, AI also allowed oppositional work against the practice (Decision 61997 ICM). It did so by recognizing "that FGM constitutes an abuse by nonstate actors and is therefore covered by Decision 5 of the 1997 ICM."29

Because oppositional work on FGM required cooperation with local NGOs and the involvement of $\mathrm{AI}$ activists in the countries where it was a widespread phenomenon, the IC specified that, in accordance with the ongoing loosening of the WOOC rule, ${ }^{30}$ sections might be allowed to work on FGM in their own countries. With this final decision on FGM, AI broadened its mandate with an issue of violence against women. It confronted the issue of governmental responsibility for inaction and tested the ways AI might hold private actors accountable. Thus, the decisions on FGM must be considered a "significant expansion into the private sphere." 31

ICM decisions concerning women's rights in general

The gradual mandate opening illustrated, among other things, the importance of the issue of FGM for future work on non-state actors. In addition to the decisions calling for an increase in AI's work on women's rights, AI also deliberated on other subjects related to violence against women in the same period. I will only mention the most important among them, which are decision 22 of the 1993 ICM and decisions 9 and 8 of the 1995 ICM. Decision 22 called for support for the UN initiative to establish a Special Rapporteur on violence against women. AI stressed that every effort should be made to use campaign opportunities to work against human rights violations against women. ${ }^{32}$ This decision echoed decision 15 of the 1989 ICM and recognized "that women suf-

29 Amnesty International, International Secretariat: The Decision of the 1997 ICM, 05.01.1998, p.12.

30 As described in Decision 48 of the 1995 ICM Work on Own Country.

$31 \quad$ Watson 1997, p.8.

32 Amnesty International, International Secretariat: 21th International Council Meeting Report and Decisions, Resolutions referred to the IEC, 1993, p.63. 
fer grave human rights violations, including rape and sexual ill-treatment and other forms of persecution directed against their sex." ${ }^{33}$

Then, in decision 9 of the 1995 ICM, the IC explicitly called to:

"examine situations where the government systematically fails to prevent, investigate and punish acts of violence against women [...], including but not limited to honor killings, bride burning and the systematic non-persecution of domestic violence."34

Similar to the decision on FGM, this decision signaled an opening of AI's working spectrum to human rights violations occurring in the private sphere. At the same time, AI extended the criteria for the adoption of prisoners of conscience, enabling the organization to also include persons imprisoned because of existing laws that make their identity "a defined element of the offense." 35 In fact, decision 8 of the 1995 ICM allowed the organization to help women detained because of their sex and to engage in promotional work against such discriminatory rules.

Whereas the ICM decisions reflect the policy frame of Al's activities, the Integrated Strategic Plans (ISPs) fix the movement's strategic direction for four to six years. ${ }^{36}$ The analysis of AI's first ISP, the Ljubljana Action Plan (LAP) 1996 - 1999, indicates where the organization put its emphasis when it comes to the implementation of the respective ICM decisions. While decisions related to AI's work on VAW ranked among the top priority issues of mandate development for the first time, ${ }^{37}$ other decisions concerning AI's work

33 Amnesty International, International Secretariat: The Decisions of the 1993 ICM, 30.09.1993, p.30.

34 Amnesty International, International Secretariat: The Decisions of the 1995 ICM, 01.09.1995, p.21.

35 Amnesty International, International Secretariat: The Decisions of the 1995 ICM, 01.09.1995, p.20.

36 Prior to 1996, Al had broadly formulated medium-term objectives (five to six years) formulated as ICM decisions (Decision 1 of the 1993 and the 1995 ICM). These objectives were criticized for not allowing adequate priority setting and demand regulation. In contrast to the medium-term objectives, the new planning instrument in the face of the ISP allowed for a rolling long-term strategic planning, integrated with financial planning (Amnesty International, International Secretariat: Strategic directions: 19951998 A discussion paper, 30.06.1993, p.16-21).

37 The LAP classified the decisions of the 1995 ICM into four areas (mandate, action, organization and development, and finances). In each of these areas, decisions were categorized either as top-priority, mid-priority, or low-priority. 
on VAW were only given medium priority, meaning that their implementation depended on resource availability. In fact, the organization stressed its intention to integrate its work on the promotion and protection of women's rights into its overall work. It also emphasized its intention to work on FGM in its promotional activities by singling the respective decisions (decision 20 1995 ICM, decision 61995 ICM) out as high-priority issues. At the same time, AI ascribed less importance to a comprehensive gender audit at all levels of the organization and to oppositional work on FGM, considering these decisions (decision 32 of the 1997 ICM, decision 6 of the 1997 ICM) of only medium priority.

Summing up, AI's human rights policy gradually shifted from its essential focus on civil and political rights and on the state as the basic violator of human rights, to adopting a mission that recognized the indivisibility of all human rights including economic, social and cultural rights. The recognition of abuses committed by political non-state actors within the mandate in 1991 was the first step of the subsequent redefinition of Al's policy away from seeing the state as the primary violator of human rights. The issue of FGM was central to AI's redefinition of its position regarding state accountability for inaction in cases of human rights violations committed by nongovernmental entities and the responsibility of private actors for abuses of human rights. In fact, FGM was the first women-specific human rights violation with which AI expanded its mandate. These mandate amendments were significant for effective action against violations of women's rights because they entailed the end of the long-lasting public-private divide inherent to the traditional understanding of human rights. They enabled the AI to take action against VAW whoever the perpetrator. The adoption of the mission, which also considered economic, social, and cultural rights, enabled the organization to campaign against VAW as a structural and social problem whose root causes resided in the social and economic subordination of women. While these policy changes indirectly contributed to making AI increase its work on issues of VAW, AI adopted three subsequent ICM decisions calling on the organization to increase its work on women's rights within the frame of the mandate. As I explain in more detail later, these decisions originated from female activists and officials in the sections, and they directly stimulated AI's activities on issues of VAW. 


\subsubsection{Policy Implementation - Al's activities on VAW within the frame of the mandate}

The present chapter concentrates on the ways AI initially integrated VAW into its activities while respecting the boundaries of the mandate. It shows that AI's work in this regard evolved considerably between 1989 and 2001. I start by providing a broad overview of AI's activities related to VAW before focusing on three major activities that the organization undertook during the same period. Combining a quantitative overview with a detailed description of these activities, I provide a comprehensive picture of the evolution of AI's activities on issues of VAW under the mandate.

The analysis of archive documents from the International Secretariat allows me to capture the approximate number and variety of activities that the organization carried out following the initial decision at the 1989 ICM. It also allows me to draw a typology of activities based on the content and the type of activity (Figure 3). ${ }^{38}$ As a reminder, the ICM decision called for increased attention and resources for the work on human rights violations against women. Based on the data, I establish two categories related to the activities' content (horizontally illustrated in figure 3): AI either addressed women's rights in general or focused on a specific case of VAW. Within this category, I distinguish between cases of VAW committed by the state or by state actors and those cases committed by private actors for which the state can be held accountable for failing to prevent or punish them. Further, I differentiate between four broad types of activities (vertically illustrated in figure 3): "Institutional measures;" "Research and campaigning;" "IGO work;" and "Outreach."

"Institutional measures" includes all activities seeking to increase the staff's and activists' awareness of women's rights issues. The type "Research and Campaigning" is comprised of reports and campaigns with a regional or a thematic focus as well as individual appeal cases and specific activities such as women's day actions. Within this type I further distinguish between activities specifically and uniquely focusing on violations of women's rights and those that added a women's branch to other thematic- or country-specific human rights reports or campaigns. Under the type "IGO work," I classified 
Figure 3: Typology of AI activities related to VAW

\begin{tabular}{|c|c|c|c|c|c|}
\hline & & & \multicolumn{3}{|c|}{ The activitiy's content: Women's rights are addressed } \\
\hline & & & \multirow[b]{2}{*}{ In general } & \multicolumn{2}{|c|}{ By focusing on a specific case of VAW } \\
\hline & & & & $\begin{array}{l}\text { Committed by the } \\
\text { state }\end{array}$ & $\begin{array}{l}\text { Committed by private } \\
\text { actors }\end{array}$ \\
\hline \multirow{6}{*}{ 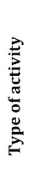 } & & Institutional Measures & & & \\
\hline & \multirow{2}{*}{$\begin{array}{l}\text { Research and } \\
\text { campaigning }\end{array}$} & Unique focus on women's rights or VAW & & & \\
\hline & & Integrated in other reports or campaigns & & & \\
\hline & \multirow{2}{*}{ IGO work } & $\begin{array}{l}\text { With organizations spezialized in women's } \\
\text { rigths or VAW }\end{array}$ & & & \\
\hline & & $\begin{array}{l}\text { With organizations working on human rights in } \\
\text { general }\end{array}$ & & & \\
\hline & & Outreach & & & \\
\hline
\end{tabular}

Source: my own, based on archival material.

AI's activities consisting in lobbying the UN or other IGOs. Again, I differentiate between IGO activities with organizations specialized in women's rights and those activities with organizations working on human rights in general. Further, I classified contact to and collaboration with women's rights groups, associations, and organizations as belonging to the "outreach" type. As I further highlight later, these women's rights NGOs constituted an important knowledge basis for AI. The collaboration with these groups enhanced AI's campaigning capacity with respect to VAW.

Figure 3 illustrates the categories according to which I classified AI's activities on VAW. Concerning the "Institutional Measures" category, AI put various actions in place to increase awareness of women's rights among staff and activists: the pilot project for decentralized work on women, the international consultation meeting in Bonn in preparation of the campaign Human Rights are Women's Rights, member training within the frame of the aforementioned campaign, and the latter's evaluation. Further, in 1996, AI established a Gender Forum ${ }^{39}$ at the IS to provide strategic advice in the implementation of the objectives regarding women's rights fixed in its long-term strategic plan (the LAP). In addition, AI issued Gender-Sensitive Research Methodology Guidelines (as demanded in decision 32 of the 1997 ICM) ${ }^{40}$ and endorsed a harassment pol-

39 The role of the Gender Forum is discussed in chapter 8.

40 Amnesty International, International Secretariat: Gender Sensitive Research Methodology Guidelines, January 1999. 
icy in 1999 (as specified in decision 2 of the 1997 ICM). ${ }^{41}$ Finally, AI organized specific training courses for staff on the issue of rape as a form of torture in preparation for the Take a Step to Stamp Out Torture campaign.

"Research and campaigning" was the most common type of activity. The predominance of research and campaign activities is not surprising, as these activities had always constituted AI's "primary organizational output." 42 As I highlight in more detail later, the 1991 report Women in the Front Line and the 1995 campaign Human Rights are Women's Rights were Al's most important actions organized in the 1990 in terms of how issues of VAW were integrated and of financial and personal resources. Besides, the IS issued several smaller country and thematic reports, and prepared numerous Appeal Cases focusing on cases of VAW committed by state actors and by non-state actors alike. AI also focused on specific cases of VAW by integrating them into other reports and campaigns. The Take a Step to Stamp Out Torture campaign launched in 2000 was the most important, as it was the first time that AI had considered VAW in the private sphere a form of torture.

Further, AI started to lobby several IGOs on women's rights around the mid-1990s. In doing so, AI's either promoted the topic within IGOs in charge of human rights issues in general, such as the $\mathrm{UN}$, or it tried to collaborate with IGOs specialized in women's rights issues, such as the CSW or the Special Rapporteur on Violence Against Women. The occasions on which AI promoted specific cases of VAW were much more rare. Examples of this were the efforts to recognize rape as a war crime in the Rome Statute and the International Criminal Court or the participation in a UN Committee drafting a protocol on trafficking of women and children in 1996. Even though AI had established links to the women's rights organization prior to the WCW, particularly, after the 1993 UN Conference on Human Rights in Vienna, most of its outreach work to women's NGOs occurred during and after the $1995 \mathrm{cam}$ paign.

The preceding paragraphs have elucidated the variety of activities AI implemented following decision 15 of the 1989 ICM. The classification of these activities according to the year of their launch allows us to see that most of them were launched in 1996 (graph 5). The significant increase in activities in 1996

41 Amnesty International, International Secretariat: Strengthening Research and Action on Human Rights Violations against Women Formulating an Implementation Strategy for the LAP (1996-2000), 06.07.1999 
is linked to the fourth WCW in Beijing 1995 and to the related campaign $\mathrm{Hu}$ man Rights are Women's Rights as well as to decision 20 of the 1995 ICM, which called for an increase in AI's work on violations of women's rights. Graph 5 also illustrates that AI's activities on the issue regressed in quantitative terms after 1996 but that they remained higher than before 1995.

Graph 5: Evolution in the number of activities, 1989-2001

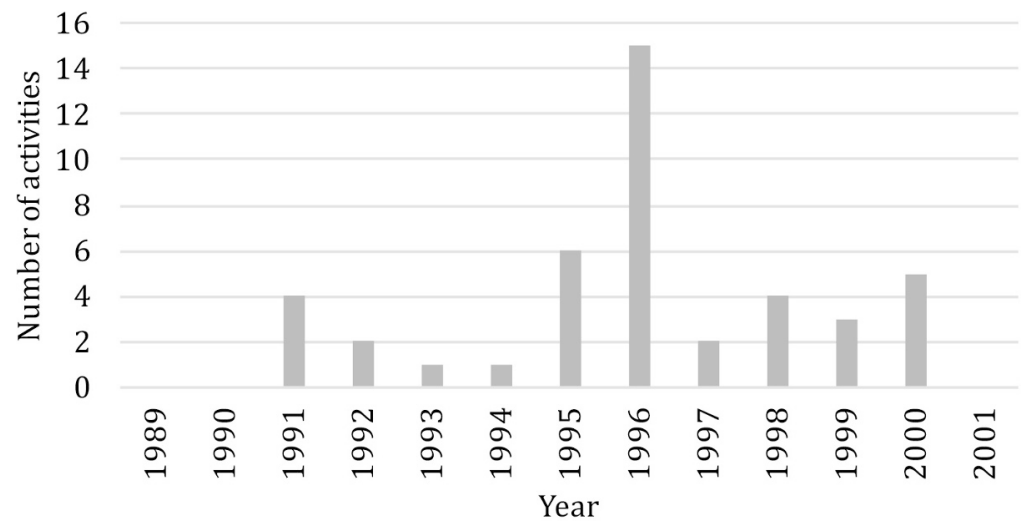

Source: my own, based on archive materials from the IS.

By classifying these activities according to their content and type, these paragraphs have provided an overview of AI's work on VAW in the 1990s. While I have commented on its variety and numeric progression, the classification does not account for the qualitative evolution of AI's work on VAW during this period. By providing a detailed account of three key activities, I chose according to information from my interviews or archival materials, the following three sections shed more light on how AI effectively integrated VAW into its activities and how this work evolved. First, I offer details on AI's first comprehensive report, Women in the Front Line, published in 1991 and the related pilot project for decentralized work on women. Then, I concentrate on the 1995 campaign Human Rights are Women's Rights, AI's first comprehensive international campaign on the rights of women. Finally, the campaign Take a Step to Stamp Out Torture illustrates how the organization included a case of VAW in a long-term thematic campaign. 


\subsubsection{Women in the Front Line}

As a result of the first ICM decision that demanded an increase in the work on women's rights (decision 15 of the 1989 ICM), the AI section in the US (AIUSA) and the IS worked out a pilot project seeking to decentralize AI's work on women from the IS to AIUSA. Within this pilot project, AIUSA was accountable to the IS for the development of AI's so-called "target sector work" for women for a period of two years, from January 1991 to December $1992 .{ }^{43}$ One of the outcomes of the pilot project was AI's first report on violations of women's rights, Women in the Front Line: Human Rights Violations Against Women. The latter introduced the issue of gender-based violence in state custody into AI's language. ${ }^{44}$ For the first time, women were not only portrayed as victims of state violence but also as political actors challenging state repression. According to AI, "the report was the first AI report ever to compile a worldwide survey of human rights violations against women" ${ }^{25}$ falling within the mandate. Eight appeal cases of women prisoners reflecting "the different kinds of human rights abuses within AI's mandate that women suffer" accompanied the release of the report. ${ }^{46}$

\subsubsection{Human Rights are Women's Rights}

AI organized its first international campaign on women's rights, Human Rights are Women's Rights, in parallel with its preparation for and participation in the fourth WCW. Therefore, this section also includes AI's involvement in the Beijing conference. In terms of employed resources, the 1995 campaign was by far the most important action on issues of VAW that AI had realized under the mandate. The campaign had two broad objectives: "define and raise the profile of AI's work on human rights abuses against women" and "pressure governments to place the indivisibility of human rights and women's rights at the heart of the WCW." 47 Benefiting from the momentum of the fourth

43 Amnesty International: Report of the Intersectional Meeting on Women and Human Rights, August 1991, p.17.

44 Roach 1994.

45 Amnesty International, International Secretariat: Women's action 1991, 1990, p.3.

46 Amnesty International, International Secretariat: Women's action 1991, 1990, p.1.

47 Amnesty International, International Secretariat: Evaluation of Theme Campaign Women and Human Rights, October 1996, p.5; Amnesty International, International Secretariat: Evaluation of Theme Campaign - Women and Human Rights, October 1996. 
WCW, AI intended the campaign to place the issue of women's rights at the top of public and the governmental concerns. ${ }^{48}$

The campaign sought to make women's civil and political rights appear in the fourth WCW's final document, mobilizing global public opinion and contributing to the ratification of all international treaties regarding women's rights by as many states as possible. ${ }^{49} \mathrm{AI}$ pushed to integrate a clear reference to states' responsibility for VAW and a number of concrete steps governments should take to end VAW into the Platform for Action, the conference's final document. ${ }^{50}$ Thus, at the Beijing conference, AI mainly concentrated on the issues of recognizing states' responsibility to end and prevent VAW, the vulnerability of women in armed conflicts, including states' responsibility to respect international human rights and humanitarian law, and states' responsibility to ensure the respect for female activists' human rights. ${ }^{51}$

AI qualified the 1995 campaign as the beginning of increased activities on women's rights: "the campaign was seen not simply as another short-term exercise but as an opportunity to 'kick-start' a comprehensive and ongoing program of activities. ${ }^{52}$ The importance of the campaign becomes evident in the number of officials and activists involved in its preparation and in the composition of AI's official delegation to the conference in Beijing, which was composed of the SG, 12 IS staff members, and 16 selected AI section participants.

The idea to realize a campaign against the violations of women's rights to accompany the movement's participation in the fourth WCW goes back to the UN Human Rights Conference in Vienna 1993. ${ }^{53}$ It became evident at the 1993 ICM two months later, where Pierre Sané stated: "We need to start planning

48 Amnesty International: Formation continue Campagne Femmes engagée - femmes en danger, 25.02.1995

49 Amnesty International: Formation continue Campagne Femmes engagée - femmes en danger, 25.02.1995

Amnesty International, International Secretariat: Report of the Fourth UN World Conference on Women Beijing, China 4-15 September, October 1995, p.13.

51 Amnesty International, International Secretariat: Report of the Fourth UN World Conference on Women Beijing, China 4-15 September, October 1995, p.24-26.

52 Amnesty International, International Secretariat: Strengthening Research and Action on Human Rights Violations against Women Formulating an Implementation Strategy for the LAP (1996-2000), 06.07.1999, p.2.

53 Amnesty International: ICM 1993: Resolutionen B, 1993. 
for Beijing now." ${ }^{4}$ Effective planning and organizing began in March 1994, when the IEC finally decided to bring this idea to fruition. ${ }^{55}$ At the movement-wide consultation meeting in Bonn in September 1994, AI clarified the content of the campaign and the strategy for its participation in the fourth WCW. Outreach activities had already started during the preparation of the campaign and AI's participation in the WCW. Participating in all of the UN regional and CSW "prepcom" meetings charged with drafting the Beijing Platform for Action, AI began to establish strong links to women's NGOs around the world. ${ }^{56}$ In addition, an Outreach Coordinator at the IS was responsible for AI networking with other NGOs at the various NGO Forum preparatory meetings. As the campaign's evaluation documents: "Sections were encouraged to explore the possibilities of developing long-term relations with NGOs, especially the major women's NGOs [...]." ${ }^{\text {57 }}$ Many sections were involved in lobbying their governments with the objective "to persuade them to adopt the position advocated by AI for the WCW." 58

Further, AI supported an international petition, addressed to the UN and asking it to fulfill its commitment to eliminate VAW. The latter was launched by a large number of organizations affiliated under the title Global Campaign for Women's Human Rights, within which AI sections contributed to the collection of "several hundred thousand signatures," 59 making it "the most successful and popular part of the [Human Rights are Women's Rights] campaign." ${ }^{60}$ At the parallel NGO Forum, where numerous IS staff and section activists repre-

\footnotetext{
54 Amnesty International: Fax from the IWN to the IEC and SC, 18.11.1993, p.1.

55 Amnesty International, International Secretariat: Evaluation of Theme Campaign Women and Human Rights, October 1996.

56 Amnesty International, International Secretariat: Key milestones of Al's work on women's human rights, 02.04.2002, p.2; Amnesty International, International Secretariat: Evaluation of Theme Campaign - Women and Human Rights, October 1996. Amnesty International, International Secretariat: Evaluation of Theme Campaign Women and Human Rights, October 1996, p.10.

58 Amnesty International, International Secretariat: Evaluation of Theme Campaign Women and Human Rights, October 1996, p.7-8.

59 Amnesty International, International Secretariat: Evaluation of Theme Campaign Women and Human Rights, October 1996, p.8.

60 Amnesty International, International Secretariat: Evaluation of Theme Campaign Women and Human Rights, October 1996, p.8.
} 
sented $\mathrm{AI},{ }^{61} \mathrm{AI}$ concentrated its outreach activities on publicity for its work, especially for its Human Rights are Women's Rights campaign, and on networking with NGOs working on women's rights. ${ }^{62}$ After the conference, the outreach to women's NGOs was one of AI's main follow-up activities. In parallel, the IS encouraged sections to continue and intensify their work with women's NGOs in their respective countries in order to ensure the government's fulfillment of the Platform of Action. ${ }^{63}$

After intensive preparations, the Human Rights are Women's Rights campaign was finally launched on the $8^{\text {th }}$ of March 1995 . The campaign's thematic focus fell on violations of women's civil and political rights. Respecting the boundaries of the mandate, it primarily highlighted the issues of VAW in situations of war and affecting female human rights defenders and women in custody. AI pointed to the particular vulnerability of female refugees, defined rape committed by state actors as an act of torture, and stressed the right of women not to be tortured, killed, arbitrarily detained or disappeared. The organization called on governments to implement stronger measures to protect women from human rights violations committed by state and non-state actors. Therefore, the state remained the main addressee of these demands. ${ }^{64}$ An important component of the 1995 campaign, which distinguished it from the 1991 action, was its message that even though women's rights were at the center of the campaign, it was not a women's campaign but a campaign for all AI members.

As far as outcomes are concerned, the evaluation of Human Rights Are Women's Rights reveals that AI considered the campaign successful, as it raised Al's profile as an organization fighting to stop and prevent human rights violations against women. Further, the fact that the campaign stimulated a significant expansion of research and action on women's rights issues, as illustrated in graph 4 , was also deemed positive. An interviewee pointed out that

61 Amnesty International, International Secretariat: Al's Presence in Beijing (Internal), 25.11.1994; Amnesty International, International Secretariat: Letter from the Project Coordinator WCW, 01.03.1995.

62 Amnesty International, International Secretariat: Letter from the Project Coordinator WCW, 01.03.1995.

63 Amnesty International, International Secretariat: "Beyond Beijing - the struggle continues" Follow-up activities on the Platform for Action, March 1996.

64 Amnesty International und International Secretariat: Evaluation Campaign 1995, December 1995 
the implication of the whole movement in the Beijing preparation process enhanced the members' awareness of the importance of integrating the work on women's rights into AI's overall work. She explains: "from the moment that all the sections started to work on the Beijing conference there was a sort of awareness building in people's mentality." 65

Moreover, the relationships established with women's NGOs during the women's campaign were judged very effective. An informant explains that AI's participation in Beijing "was a very successful attempt by Amnesty. For the first time Amnesty became accepted, was accepted very well by the key female leaders in the movement." ${ }^{66}$ At the same time, the limitation fixed by the mandate and the WOOC rule hindered some sections' attempts to reach out to women's rights NGOs because AI could not address the issue of domestic violence. ${ }^{67}$ In addition, the evaluation also stated that other factors hampered the success of the campaign, such as the delayed decision to undertake the campaign, the under-staffing affecting campaign work at the IS, inadequate research information on some subjects, and the fact that the preparation of AI's participation in Beijing took time and resources needed for the broader campaign. ${ }^{68}$ In sum, the lack of human and/or financial resources was considered the main obstacle to effective campaigning. ${ }^{69}$

Consequently, Women in the Front Line and Human Rights are Women's Rights were Al's first comprehensive international research and campaign activities addressing cases of VAW as covered by the mandate. The 1995 campaign focused on a range of women-specific human rights violations covered by the mandate and tackled states' responsibility to end VAW committed by private actors, such as trafficking or FGM. Nevertheless, AI still defined itself as a

65 Ganzfried: Interview with A.J., 09.03.2012: "Il n'y avait pas systématiquement tous les rapports qui parlait de ça mais dès le moment ou après toutes les sections se sont mise à travailler par rapport à la conférence de Beijing il y a un espèce de awareness building dans la mentalité des gens.".

66 Ganzfried: Interview with A.O., 23.01.2015.

67 Amnesty International, International Secretariat: Evaluation of Theme Campaign Women and Human Rights, October 1996, p.10; Amnesty International, International Secretariat und Amnesty International, International Secretariat: 1997 Meeting of the Intersectional Women's Network (IWN), May 1997.

68 Amnesty International, International Secretariat: Evaluation of Theme Campaign Women and Human Rights, October 1996, p.11-12.

69 Amnesty International, International Secretariat: Evaluation of Theme Campaign Women and Human Rights, October 1996, p.11. 
movement "that works to prevent some of the gravest violations by governments of people's fundamental human rights." ${ }^{70}$ Even though archive materials do not allow me to define the exact financial and personal resources $\mathrm{AI}$ destined to the activities related to the fourth WCW, compared to the pilot project and the Women in the Front Line report, which was mainly carried out by a team of two officials at the US section and the IS, AI substantially increased the financial and personal resources available for the Human Rights are Women's Rights campaign. More importantly, through the 1995 campaign and its active participation in the fourth WCW, AI enhanced its staff and activists' awareness of women's rights and became a valuable partner of women's rights organizations in their struggle to make the international community consider women's rights as human rights.

The campaign has been criticized for "continue[ing] to reproduce an image of passive, dependent women who need paternal families and states to protect them." As explained by Bahar, "this image ultimately relies on assumptions of a patriarchal family where female child-rearers depend on strong male figures for protection." ${ }^{71}$ In addition to specific women's rights activities, such as the 1991 report and the 1995 campaign, by the late 1990 s the organization had started to consider the issue of VAW in broader thematic campaigns, such as the one on torture, within which AI considered VAW in the private sphere as an act of torture for the first time.

\subsubsection{Take a Step to Stamp Out Torture}

The Take a Step to Stamp Out Torture campaign was launched in October 2000 and can be considered the most important example of the integration of VAW into a thematic campaign. More important, it was the first international thematic campaign where AI defined VAW in the private sphere as an act of torture. According to an interviewee, the campaign signaled the beginning of AI's work on women's rights in the private sphere: "AI started doing women's rights work and LGBT and sexuality work under the torture campaign." ${ }^{72}$ In fact, identity-based abuses such as torture based on gender, sexuality or race constituted core issues of the campaign. In the main campaign document, AI explains that "Many forms of violence against women in the home and in the

70 Amnesty International, International Secretariat: Campaign on women and human rights - theme leaflets, 07.03.1995, p.2.

$71 \quad$ Bahar 1996, p.117.

72 Ganzfried: Interview with A.W., 25.06.2012. 
community may also constitute torture or ill-treatment. The harm inflicted is often the same or comparable to that which is inflicted on women who are tortured in custody."73

The IS published a specific report on torture and ill-treatment of women within the campaign, underlining AI's aim of holding "states accountable for all acts of torture of women, whatever the context in which they are committed and whoever is the perpetrator." ${ }^{74}$ In fact, by defining cases of VAW in the private sphere as acts of torture, AI applied the International Convention on Torture, a "hard" human rights standard, to women. The work on VAW carried out within the torture campaign was significant, as "Under the rubric [of the torture campaign AI] first began to do the sexuality work using one of the hardest standards in international law, hard law, black letter law, it is an absolute standard, there is no excuse to undermine it." 75 However, as I show later, this new approach seems to have been unsustainable in the SVAW campaign. AI "moved from 'black letter standard' to soft law"76 addressing VAW in the private sphere, such as domestic violence, not as a matter of state accountability but foremost under the concept of due diligence entailing a focus "on the state obligation to create conditions to prevent and adequately respond to violence against women perpetrated by non-state actors."77

Summing up, the present section has highlighted the ways in which AI initially integrated VAW into its activities respecting the boundaries of the mandate and shown that AI's work evolved considerably between 1989 and 2001. Whereas the report Women in the Front Line focused on gender-based violence in state custody and highlighted patterns of political persecutions of women, the Human Rights are Women's Rights campaign focused on torture, the death penalty, extra-judicial executions, and disappearances as they affected women. It also tackled states' responsibility to end VAW committed by private actors such as trafficking or FGM. However, similar to its first report, the state remained the primary addressee of the organization's demands to prevent and condemn VAW. By independently considering all forms of VAW as acts

73 Amnesty International, International Secretariat: Take A Step To Stamp Out Torture, 2000, p.28.

74 Amnesty International, International Secretariat: Broken bodies, shattered minds Torture and ill-treatment of women, 2001, p.4.

75 Ganzfried: Interview with A.W., 25.06.2012.

76 Ganzfried: Correction of citations A.W., 22.08.2018.

77 Benninger-Budel 2008. 
of torture, whatever their context and whoever their perpetrator, the Take a Step to Stamp Out Torture campaign can be seen as AI's first effective attempt to campaign against VAW in the private sphere.

Even though AI's activities on the issue of VAW increased tremendously during the 1990s, both in quantitative and qualitative terms, an internal report from 2000 stated: "the sum of all activities undertaken since 1995 does not amount to institutionalization nor does it amount to sustainability."78 Evidence indicates that despite the intensification of its fundraising efforts and the reallocation of resources following the 1995 ICM, a lack of resources continued to plague efforts to make women's rights an integral part of AI's work. ${ }^{79}$ For example, the medium priority given to the execution of a gender audit in the LAP (decision 32 of the 1997 ICM) and financial cuts in the IS impeded the realization of a comprehensive gender-based evaluation of the whole movement as demanded at the 1997 ICM. ${ }^{80}$

The previous two sections have delineated policy developments regarding VAW and emphasized the evolution of AI's body of work. However, they have remained silent on the origins of this progress. The following section fills this knowledge gap and shows that feminist strategizing is key in comprehending why AI started to do work on VAW and in understanding the subsequent increase in the latter.

\subsubsection{Feminist strategizing}

As mentioned in chapter 2.3, external and internal factors are known to have contributed to AI's growing interest in issues of VAW. The changing patterns of human rights violations contributed to making $\mathrm{AI}$ question its statefocused mandate, ${ }^{81}$ thereby facilitating work on violations of women's rights. Further, the growing international awareness of gender equality stemming from the UN Decade for Women 1975-1985 and the related WCWs, especially

Amnesty International, International Secretariat: Final Implementation Report of the Ljubljana Action Plan, 1996-2000, July 2000, p.8.

79 Amnesty International, International Secretariat: Evaluation of Theme Campaign Women and Human Rights, October 1996, p.15.

80 Amnesty International, International Secretariat: Letter from Habiba Hasan (IEC member with brief on Women \& gender) giving an update on the Gender Audit and Intersectional Women's Network, November 1998.

81 Thakur 1994; Pack 1999. 
the conference in Beijing, affected AI's approach to women's rights. ${ }^{82}$ At the same time, the international women's rights movement challenged mainstream human rights organizations, such as $\mathrm{AI}$, to expand their mandate to violations of human rights in the private sphere. ${ }^{83}$ The positive stance of the SG Pierre Sané, who "took a leading role in enunciating Amnesty's support for women's rights [...]," ${ }^{84}$ the growing number of women occupying management positions at the IS, and activists' lobbying the organization to work on women's rights more seriously are all internal factors known to have contributed to AI's increasing interest in issues of VAW.

Aware of these external and internal factors, the present section demonstrates that the feminist strategies of parallel networking and analogous framing were crucial in increasing AI's interest in issues of VAW. They also explain the decision to launch a first global theme campaign on VAW. Even though female activists and officials within AI would not necessarily have perceived their strategies as feminist, I define them as feminist because they were set up by women and ultimately challenged the underlining gender hierarchy inherent to AI's conception of human rights. ${ }^{85}$

I argue that by setting up the IWN, female activists and officials were able to internally lobby to increase AI's work on violations of women's rights in an effective way. Organizing in an intersectional network allowed female activists and officials to reach out to the whole AI movement and find majorities for their demands at the ICMs. Parallel networking was thus one of the strategies used to influence AI's agenda. I call the strategy parallel networking because the IWN was based on AI's overall transnational-network structure. At the same time, female activists and officials called for an increase in AI's work on women's rights within the frame of the mandate. They thus used a strategy of analogous framing because by demanding an intensification of the organization's work on violations of women's civil and political rights, rather than calling for the end of AI's state-focused mandate, they framed their demand in a manner analogous to AI's overall policy. Similar to the strategy of parallel networking, this strategy was crucial in making AI increase its work on VAW because it allowed female activists to garner the majority of the movement's support to engage more seriously with women's rights.

\footnotetext{
82 Bunch 2001.

83 Bahar 1996.

84 Kelleher and Bhattacharjya 2013, p.4.

85 Sperling et al. 2001.
} 
The section begins by providing initial evidence of the IWN as a vector for change in the 1990s. It proceeds to trace the foundation of the network and highlight female activists' role in initiating AI's work on violations of women's rights that falls within AI's mandate in the late 1980s. The section follows up by highlighting the lack of sustainability of the pilot project for decentralized work on women established following decision 15 (1989 ICM). The section on the UN Conference on Human Rights and the fourth WCW demonstrates how IWN members continued to push the implementation of decision 15 of the 1989 ICM and the adoption of the related follow-up decision at the 1995 ICM (decision 20). In particular, the 1995 WCW in Beijing became a window of opportunity for the lobbying efforts of female activists and officials who wanted the organization to increase its work on VAW and facilitate the integration process. Later, the section illustrates that with the appointment of an IWN coordinator at the IS, the network members changed their lobbying efforts and began to target the essence of AI's work, namely research. The section concludes by establishing that continuing pressure from female activists and officials at various levels organized in the IWN finally led the IEC to decide to launch AI's first global thematic campaign on VAW in 2001.

Several archive documents and secondary publications illustrate the importance of the IWN for making AI increase its work on issues of VAW. This significance proves the existence and the effectiveness of a feminist strategy of parallel networking. Internal voices from both the IS and sections emphasized the network's importance "[...] in raising the profile of AI's work on women's rights in their countries as well as globally." 86 They identified the IWN as "responsible for many of the strides made in AI's work on women's rights and in particular on VAW prior to the launch of the SVAW campaign." ${ }^{87}$ According to Kelleher and Bhattacharjya (2013), "The IWN [...] contributed to the pressure on the IS to bring women's rights to their work." ${ }^{88}$ IWN members themselves emphasized their network's substantial contribution to monitoring the insti-

\footnotetext{
86 Amnesty International, International Secretariat: 2002 Intersectional Women's Network (IWN) Meeting, October 2001, p.1.

87 Amnesty International: Al and a new international women's rights network, November 2009, p.6.

88 Kelleher and Bhattacharjya 2013, p.3.
} 
tutionalization of gender within $\mathrm{AI}^{89}$ and qualified it as a vector for change for the sections. ${ }^{90}$

In fact, the IWN was founded by female activists as an intersectional advisory group with expertise on women's rights issues in the early 1990s. While de facto open to all members, the network was mainly composed of female activists and officials. ${ }^{91}$ It developed from "an informal grouping of women's activists" 92 without a formal standing in 1991 into an officially recognized network ${ }^{93}$ of 58 sections by $2001 .{ }^{94}$ According to an IS document:

"the IWN has evolved over the years from a loose and informal structure with most of its members not having a formal status in sections to a network composed of individuals or groups or networks or committees set up by sections to specialize on their work on women's rights." 95

Combining the IWN's significance in causing AI to strengthen its work on issues of VAW with the fact that all previously described ICM decisions directly concerning VAW (underlined in Figure 4) were based on resolutions initiated by sections (Figure 4$)^{96}$ suggests that the members of the IWN must have pushed policy developments in AI's work on issues of VAW. In fact, I show

89 Amnesty International, International Secretariat und Amnesty International, International Secretariat: 1997 Meeting of the Intersectional Women's Network (IWN), May 1997, p.7.

90 C. und C.: IWN meeting, April 2002.

91 Amnesty International: Amnesty International Intersectional Women's Network Member List, 1995; Amnesty International, International Secretariat: 2002 Intersectional Women's Network (IWN) Meeting, October 2001; Amnesty International, International Secretariat: Information pack for Intersectional Women's Network, May 2001

92 Amnesty International, International Secretariat: Letter from Habiba Hasan (IEC member with brief on Women \& gender) giving an update on the Gender Audit and Intersectional Women's Network, November 1998, p.2.

93 The IEC approved the IWN's Terms of References (TORs) in April 1998 (Amnesty International, International Executive Committee: IEC Information Bulletin No. 23, April 1998b).

94 Amnesty International, International Secretariat: Information pack for Intersectional Women's Network, May 2001.

95 Amnesty International, International Secretariat: Information pack for Intersectional Women's Network, May 2001.

96 Decision 6 of the 1995 ICM goes back to an initiative of the Luxembourg section (formulated in decision 10 of the 1993 ICM) instructing the IEC to present recommendations on how Al should deal with FCM at the next ICM (Amnesty International, International Secretariat: The Decisions of the 1993 ICM, 30.09.1993, p.14). 
that the members of the IWN mostly concentrated on the adoption and implementation of those decisions made at the 1989, 1995, and 1997 ICMs that called for an increase in AI's work on women's rights within the mandate (underlined and in italic in Figure 4). I thus present analogous framing as one of the strategies female activists and officials employed to affect AI. Female activists also seemed to have initiated policy development on FGM: "working on the issue of FGM was, at the time, a demand from the women of the South, from African women." 97 However, this concern was not the focus of the IWN's lobbying efforts. ${ }^{98}$

Figure 4: The origin of ICM decisions

\begin{tabular}{|c|c|}
\hline \multicolumn{2}{|c|}{ ICM decisions based on a resolution initiated by } \\
\hline sections & the IEC \\
\hline $\begin{array}{l}\text { Decision } 151989 \text { ICM Human rights violations against } \\
\text { women } \\
\text { Decision } 101993 \text { ICM Female Genital Mutilation } \\
\text { Decision } 221993 \text { ICM UN Rapporteur on Women } \\
\text { Decision } 91995 \text { ICM Women } \\
\text { Decision } 201995 \text { ICM Work on behalf of Women } \\
\text { Decision } 31997 \text { Mandate Review } \\
\text { Decision } 61997 \text { ICM FGM } \\
\text { Decision } 321997 \text { ICM Action on Human Rights } \\
\text { Violations against Women }\end{array}$ & $\begin{array}{l}\text { Decision } 61995 \text { ICM Governmentalinaction and FGM } \\
\text { Decision } 51997 \text { ICM Abuses by Non-state Actors } \\
\text { Decision } 31999 \text { ICM Mandate Review } \\
\text { Decision } 32001 \text { ICM Statute amandment: Vision and } \\
\text { Mission of Amnesty International } \\
\text { Decision } 132001 \text { ICM Work on own country } \\
\text { Decision } 72001 \text { ICM Mandate: Economic, Social and } \\
\text { Cultural Rights } \\
\text { Decision } 62001 \text { ICM Mandate Review }\end{array}$ \\
\hline
\end{tabular}

Source: ICM reports

Months of internal discussions and lobbying from female AI section activists heralded the adoption of decision 15 at the 1989 ICM. In fact, activists' complains about the systematic under-representation of women in the cases investigated by AI dates back to the late 1980 s. ${ }^{99}$ In this period, the lack of cases involving women seemed striking: "In 1987, of the thirty-three prisoner cases carried in Amnesty's International Newsletter, only three were women and, of the eleven cases initially highlighted in 1988 as part of the 'Human

97 Ganzfried: Interview with B.N., 06.06.2013: "De travailler contre les mutilations génitales, c'était une demande à l'époque des femmes du Sud, donc des femmes africaines [...]." Ganzfried: Interview with A.J., 09.03.2012.

98 The composition of the IWN, whose members mostly came from Western sections may be one reason for this focus. In fact, in 1995, only 1 of 30 members came from an African section (namely Tanzania).

99 Roach 1994. 
Rights Now!' tour, only one was a woman."100 The following statement colorfully illustrates the activists' concern about the absence of women among AI cases from AIUSA's perspective:

"In 1988, Amnesty members from around the United States came together in a membership meeting and they said, 'You know, we've got some reports, we've looked at the materials, and women are really just missing. These are great reports and they are really important. But turning the pages, what you have is case of man after man after man after man-on whose behalf we do want to work. But where are the women?'"101

As a result, in 1989, US section members used an Annual General Meeting Resolution to call upon AIUSA to strengthen work on behalf of the protection of women's human rights. ${ }^{102}$ A large majority of AIUSA members accepted the resolution. The section's board of directors sent a letter to the IEC and to the IS notifying them, among other things, that "Work on women needs to be more comprehensive and visible at every level of the movement"103 and offering "to help in any feasible way, including devoting additional resources to the task." 104

Because they "were really sick and tired of the IS becoming very gender blind," ${ }^{105}$ AI members in Germany, Switzerland, Britain, and Ireland pressured their sections to demand a better integration of women's rights into AI's overall work from the SG and the IEC, as well. ${ }^{106}$ These section initiatives heralded the forming of the IWN.

Then, at the 1989 ICM, a group of section delegates gathered together in an informal meeting to talk about the issue of how to start working on women's rights and "brought back a resolution to the full body that called for strengthening Amnesty's work for women at every level of the organization."107 The

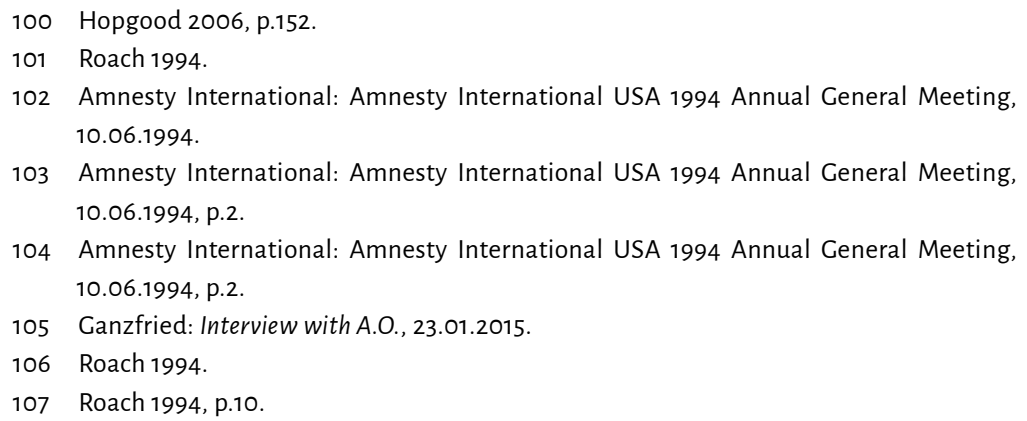

106 Roach 1994.

107 Roach 1994, p.10. 
resolution was subsequently adopted as decision 15 . The adoption of decision 15 can be interpreted as the first success of the feminist strategy of analogous framing, as the decision called on "the movement to strengthen its work on behalf of women" ${ }^{\prime 108}$ as covered by the mandate. During this informal meeting, the participants agreed to develop a "network of representatives from Amnesty sections and groups around the world interested in promoting AI's work for women"109 and decided that AIUSA should coordinate the development of the network. ${ }^{110}$

Consequently, this informal meeting of female delegates at the 1989 ICM can be seen as the origin of the IWN or the beginning of a feminist strategy of parallel networking meant to make AI increase its work on women's rights. The testimony of a participant in the informal meeting at the 1989 ICM reveals the female activists' hope about this first achievement: "We were so happy when we heard [that the resolution passed]. We thought, "This is it! This is the breakthrough. This is what we've been waiting for."'111

The IWN was established (without having recognized Terms of References) at the first intersectional meeting on AI's work on women's rights in Geneva in February 1991. This first intersectional meeting ${ }^{112}$ was meant to push the further development of Al's work for the protection of women's human rights. The Swiss and the US sections co-hosted the gathering ${ }^{113}$ and the engagement of individual female activists seems to have been important for the organization of the event, as the Swiss section initially refused to organize the meeting because of the lack of "logistic possibilities to do it."114 The efforts of some female activists finally made it possible to organize the conference in Geneva. The results of the meeting, attended by representatives from $26 \mathrm{sec}-$ tions, were the forming of the IWN and the adoption of recommendations,

108 Amnesty International: Amnesty International USA 1994 Annual General Meeting, 10.06.1994, p.2.

Amnesty International: Report of the Intersectional Meeting on Women and Human Rights, August 1991.

Amnesty International, International Secretariat: Report of the Intersectional Meeting on Women and Human Rights, August 1991, p.2.

111 Roach 1994, p.10-11.

112 The 1991 meeting was later referred to as the first meeting of the IWN.

113 Amnesty International: Report of the Intersectional Meeting on Women and Human Rights, August 1991.

114 Ganzfried: Interview with A.B., 12.04.2012. 
which "were [subsequently] sent to the IS, IEC, and all sections." ${ }^{\text {"15 }}$ Nevertheless, as I detail hereafter, except for the establishment of the IWN, most of the recommendations have not been implemented because of the lack of financial and personnel resources. ${ }^{116}$

In parallel with the forming of the IWN and as a result of the decision 15 (1989 ICM), the IS and AIUSA worked out the pilot project for decentralized work on women, according to which an AIUSA staff member "worked part time as a member of the IS campaign unit to ensure the integration of work for women in campaigns and actions." 117 Additionally, the IS "target sector coordinator who was also responsible for trade unionists, children, religious groups, journalists, engineers, etc." ${ }^{\text {"18 }}$ was given "women" as an additional target sector. ${ }^{119}$ In a separate arrangement, an AIUSA staff member was given permission to "research IS material on women" 120 and the AIUSA women's task force identified "patterns of abuse that were gender-based." ${ }^{21}$ The outcome of these efforts was the publication of AI's first comprehensive report on the violation of women's rights, Women in the Front Line, in March 1991. However, this first "substantive and effective work"122 on women rights violations was not sustained. By the end of the pilot project in 1993, the work on women's rights issues was handed over to two IS staff persons already responsible for work on the death penalty, political killings, and disappearances. These staff members "made it clear they had no time or resources to devote to women's

115 Amnesty International: Amnesty International USA 1994 Annual Ceneral Meeting, 10.06.1994, p.2.

116 Amnesty International: Amnesty International USA 1994 Annual Ceneral Meeting, 10.06.1994; Amnesty International: Internationale Tagung über die ai-Kampagne für die Menschenrechte von Frauen, Bonn, 16.-18. September 1994, October 1994.

117 Amnesty International: Amnesty International USA 1994 Annual Ceneral Meeting, 10.06.1994, p.2.

118 Amnesty International: Amnesty International USA 1994 Annual Ceneral Meeting, 10.06.1994, p.2.

119 AIUSA, 1994 Annual Ceneral Meeting, June 10-12, Chicago, Illinois, Doc. 052.013, 49.

120 AIUSA, 1994 Annual General Meeting, June 10-12, Chicago, Illinois, Doc. 052.013, 49.

121 Roach 1994, p.11.

122 Amnesty International: Amnesty International USA 1994 Annual Ceneral Meeting, 10.06.1994, p.3. 
human rights issues."123 Further, the funding of the IWN was neither truly clarified nor sufficient in the first years. ${ }^{124}$

Concerned about the decline in work on women's human rights violations, the Canadian and the US sections pushed for an improvement by writing letters to the SG and the IEC. In a letter addressed to Pierre Sané, the Canadians expressed their "anxiety regarding the inadequate level of activity within AI concerning human rights violations against women"125 and asked "that the steps taken by AI towards addressing human rights violations against women be strengthened, as per 1989 ICM Decision 15 [...]."126 At the same time, the Chair of the AIUSA Board of Directors urged the IEC to make a commitment and allocate resources to ensure "that a focus on women is automatically integrated into our ongoing work including research, campaigns, press and publications." ${ }^{127}$ These letters were not signed by IWN members. However, given that the AIUSA member of the IWN had been especially engaged in pushing AI to increase its work on women's rights violations and that she continued to push her section in this regard, it is worth assuming that IWN members must have been behind these initiatives. Further, as I show subsequently, the IWN members of the US and the Canadian sections were particularly engaged in pressuring their section to make the movement strengthen its work on violations of women's rights.

Even though the IWN coordinator described her network at the time of the 1993 ICM as "not organized," 128 IWN members capitalized on the UN Conference on Human Rights in 1993. In fact, IWN members from different AI sections ${ }^{129}$ organized a meeting titled "AI and Women's Human Rights" during the conference and reiterated "their concerns regarding the inadequate level of activity within $\mathrm{AI}$ concerning human rights violations against

123 Amnesty International: Amnesty International USA 1994 Annual General Meeting, 10.06.1994, p.3.

124 Amnesty International: Internationale Tagung über die ai-Kampagne für die Menschenrechte von Frauen, Bonn, 16.-18. September 1994, October 1994.

125 Amnesty International: Letter to the IS concerning Al's work on women's rights, 27.04.1993, p.1.

126 Amnesty International: Letter to the IS concerning Al's work on women's rights, 27.04.1993, p.2.

127 Amnesty International: Letter from the Chair of the Board of Directors of AIUSA to the Chair of the IEC, 10.05.1993, p.1.

128 Roach 1994, p.11.

129 The Austrian, British, Canadian, Dominican, German, and the US sections. 
women." 130 During this meeting the IWN members agreed to urge their respective sections to send letters similar to those previously issued by the US and the Canadian sections. Further, they agreed to ask their delegates to the 1993 ICM to push for a major campaign on women's human rights violations around the $1995 \mathrm{WCW} .^{131}$

As a result, several sections finally complained about the poor implementation of decision 15 (1989 ICM) to the IEC $^{132}$ and others intervened at the 1993 ICM. The German section, for example, submitted a resolution ${ }^{133}$ to the 1993 ICM asking to "capitalize on the event of the UN World Conference on Women to be held in Beijing in 1995 to campaign on human rights violations against women." ${ }^{134}$ The Austrian section actively supported the German resolution in a letter to the ICM delegation and to the German section. ${ }^{135}$ At the 1993 ICM itself, the IWN members "got [their] directors to complain and say that [they] absolutely had to do better work than [what they] had been doing." ${ }^{136}$ Additionally, the AIUSA Women's Human Rights Steering Committee called the SG and the IEC to undertake additional steps to strengthen its work on women's rights in October $1993 .{ }^{137}$

Following these diverse lobbying efforts from IWN members, the IEC organized a movement-wide consultation on a possible theme campaign and decided (based on its outcome) to launch a campaign on human rights violations against women in view of the upcoming fourth WCW. ${ }^{138}$ Additionally, by mid-1994 the IEC assigned a member of the IWN as the first holder of the Spe-

130 Amnesty International: Minutes of the meeting "Al and Women's Human Rights" at the UN World Conference on Human Rights in Vienna, 1993, p.1.

Amnesty International: Minutes of the meeting "Al and Women's Human Rights" at the UN World Conference on Human Rights in Vienna, 1993.

132 Amnesty International, International Secretariat: Report of the meeting of the IEC 1518 April 1994, 26.07.1994, p.39.

133 Resolution B37, see appendix 2.

134 Amnesty International, International Secretariat: 21th International Council Meeting Report and Decisions, Resolutions referred to the IEC, 1993, p.94.

135 Amnesty International: Letter from the Austrian Section to the ICM Delegation 1993 and to the German section, 07.07.1993.

136 Roach 1994, p.11.

137 Amnesty International: Amnesty International USA 1994 Annual General Meeting, 10.06.1994.

138 Roach 1994. 
cial Brief on Women ${ }^{139}$ within the IEC with the objective of increasing the attention to women's rights at all levels, especially within research, ICM resolutions, campaigns, and publications. ${ }^{140}$ Having a representative within the IEC marked an important advance for the IWN members, as their demands were backed from within an AI's governing body from then on. Whereas archive material does not allow me to determine the exact origin of the idea to establish this Special Brief, the following extract from the IEC meeting shows that the IWN clearly backed its creation: "there has been support from sections, namely the inter-sectional network, for the development of the Brief."141

The IWN was closely involved in the planning and organization of the $\mathrm{Hu}$ man Rights are Women's Rights campaign and used the opportunity presented by the fourth WCW to continue pressuring for sustained work on women's rights within the whole movement. At the international consultation meeting for the preparation of the Human Rights are Women's Rights campaign in Bonn in September 1994, ${ }^{142}$ which was initiated by the German section's member of the IWN, the IWN members formulated demands for AI's future work on women's rights. They asked the IEC to make more resources at the IS available for the work on women's rights leading up to Beijing and wanted the IEC-Brief on Women to become a permanent institution. ${ }^{143}$ At the Bonn meeting, which became known as the IWN's second meeting, the IWN additionally agreed to increasingly target sections "to make them collectively push AI's work on persecuted women and to influence the SCM, the ICM and the IEC."144

At the same time, as the following extract from a letter from the IWN coordinator to the members indicates, the network continued pushing for the

139 Amnesty International International, Executive Committee: IEC Information Bulletin No. 12, 17.10.1995, p.30; Ganzfried: Interview with A.O., 23.01.2015.

140 Gruber und Frauenkommission Sektion der Bundesrepublik Deutschland: Letter from the Women's group of Al Cermany to the AI German section, 05.10.1994, p.2.

141 Amnesty International, International Secretariat: Report of the meeting of the IEC 1518 April 1994, 26.07.1994, p.39.

142 Amnesty International: Internationale Tagung über die ai-Kampagne für die Menschenrechte von Frauen, Bonn, 16.-18. September 1994, October 1994.

143 Amnesty International und Stuttard: Bonn Meeting - Summary of minutes, 04.11.1994; Amnesty International und Svorad: Bericht über die Tagung in Bonn, 09.1994.

144 "[l]ndem mehrere Sektionen gemeinsame Vorstösse für verstärkte ai-Arbeit für verfolgte Frauen unternehmen und Einfluss aufs SCM, ICM, IEC usw. ausgeübt wird." (Amnesty International: Internationale Tagung über die ai-Kampagne für die Menschenrechte von Frauen, Bonn, 16.-18. September 1994, October 1994, p.5). 
adoption of another ICM decision that would force AI to allocate the personnel and financial resources necessary for sustained work on violations of women's rights at all levels: "It is very important that as a network we begin now to develop a strategy that will ensure strong support from our section ICM delegates for allocating resources to support substantive work for women in the movement."145

As a result of the IWN members' lobbying, AI appointed a part-time women's rights coordinator at the IS who was responsible for the coordination of the Human Rights are Women's Rights campaign and of the IWN, in addition to other briefs. In fact, following a mutual agreement, AIUSA handed the IWN coordination over to the IS in early $1995 .{ }^{146}$ As I develop later, the centralization of the IWN coordination changed the focus of the IWN members' lobbying. At the same time, the IWN members' pressure on sections also bore fruit. In fact, as a letter from the coordinator to the IWN members highlights, "in about seven sections around the world, [IWN members] have brought forward very specific resolutions"147 to submit to the 1995 ICM. ${ }^{148}$ In light of the upcoming 1995 ICM, the IWN coordinator insisted in a letter to the members: "It is urgent that your delegation a.) Understand and support the resolution, and b.) Be willing to lobby delegates from other sections to support it as well." ${ }^{149}$

Finally, the US, the Canadian, the Austrian, the Irish, the Venezuelan, and the UK sections submitted three resolutions to the 1995 ICM requesting the integration of the work on women's rights into AI's overall work at all levels. ${ }^{150}$ In resolution $\mathrm{B} 4.2$, the US, the Canadian and the Austrian sections called for the creation of a staff position at the IS responsible for the work on women's human rights, among other things. ${ }^{151}$ By submitting resolution B4.3, the Irish section called for a clarification of the mandate in order to work on a broad

145 C.: Letter to the IWN members, 17.06.1994.

146 See the list with the names of the IWN coordinators in appendix 1. (For a short period of time (July to September 1995) Susanne Reichinger from AI Germany held the role of coordinator.).

147 Roach 1994, p.11.

148 Amnesty International: Internationale Tagung über die ai-Kampagne für die Menschenrechte von Frauen, Bonn, 16.-18. September 1994, October 1994, p.6.

149 C.: Letter to the IWN members, 10.03.1995.

150 For details on the resolutions, see appendix 2.

151 Amnesty International, International Secretariat: International Council 1995 Circular XII, 03.03.1995. 
number of violations of women's human rights. The UK section demanded the organization of a movement-wide gender analysis of its structure and work in resolution B4.4. Decision 20 of the 1995 ICM integrated all the demands brought forward in these resolutions except for the request of a comprehensive gender audit.

Thus, the female activists' and officials' strategies of parallel networking and analogous framing reaped its first successes by 1995 . After the adoption of the first ICM decision calling for increased attention and resources for work on human rights violations against women at the 1989 ICM, female activists and officials forced the movement to further increase its work on this issue in decision 20 of the 1995 ICM. Organizing in an intersectional network and formulating their demands in accordance with the mandate were pivotal for the achievements at the policy level as this allowed them to reach out to the whole AI movement and build majorities for their demands at the ICMs. In their quest, the fourth WCW appeared as a window of opportunity to enable female activists and officials to enhance their lobbying efforts and make AI launch its first major theme campaign on women's rights. The creation of the Special Brief on Women at the IEC and the appointment of a women's rights coordinator at the IS, whose responsibilities included coordinating the IWN, can also be considered a consequence of the IWN members' lobbying efforts.

The feminist strategies of parallel networking and analogous framing were also bearing fruit at the national level. In fact, as revealed in the IWN survey, most of the sections developed their work on women's rights around the 1995 campaign: “Although some sections' work on women's rights dates back to the 1980 s, most (92\%) has been established since $1991.75 \%$ of the sections have established their work on women's rights since the 1995 campaign." 152 Many national women's groups or networks formed after 1995, and some sections appointed women's rights coordinators in charge of the coordination of activities on the issues with the IS and other sections. ${ }^{153}$ In many cases, these sectional focal points were members of the IWN at the same time. I detail the development of the work on VAW within sections in the upcoming pages about the Swiss and the German sections.

\footnotetext{
152 Amnesty International, International Secretariat: Al Intersectional Women's Network Survey 2001 - Brief Overview of Results, 2002.

153 Amnesty International, International Secretariat und Amnesty International, International Secretariat: 1997 Meeting of the Intersectional Women's Network (IWN), May 1997, p.6.
} 
As I have highlighted before, until the 1995 campaign, the women organized in the IWN mostly lobbied their sections, the SG, and the IEC in order to make AI increase its work on women's rights, focusing on decision-making and implementation. With the centralization of the IWN coordination at the IS, the IWN also increasingly emphasized the lifeline of the organization - namely, research. Having evaluated the movement's achievements with respect to the IWN goals by the end of the 1995 campaign, an interviewee explained: "we [the IWN] have done very well in our contacts with the women's movement, we have done very well in terms of strengthening our female activists, we have done very well in terms of our presence at the UN but 'What do we do with research?"'154 As the following statement shows, and as I develop further hereafter, the new IWN coordinator at the IS established her own strategy to make AI increase its work on women's rights issues:

"[She] took [her] briefs, [she] developed [her own strategy that [she] will make use of the section's network of women focal points [...]. So together with them [she] strategized, [she] built their capacities, [she] gave them a bigger voice in Amnesty in terms of criticizing Amnesty's reports where there could have been more visibility for women, etc. etc."155

In fact, a group of officials at the IS clustered around the IWN coordinator organized the systemization of gender analysis in AI's research reports. As a consequence of decisions 20 of the 1995 ICM, the SG appointed Agnes Callamard, a women's rights activist and academic, to the position of ResearchPolicy Coordinator to help build the researchers' capacities for gender analysis in $1997 .{ }^{156}$ As an informant explains, whereas the IWN coordinator was more "a campaign and capacity building person,"157 Callamard brought along a "solid background in terms of policy and developing research frameworks"158 and therefore, had the necessary "credibility to provide [the researchers] with tools for gender analysis." 159 Additionally, another colleague "was looking at what is Amnesty's state in terms of IGO at the UN." ${ }^{160}$ According to the same

\footnotetext{
154 Ganzfried: Interview with A.O., 23.01.2015.

155 Ganzfried: Interview with A.O., 23.01.2015.

156 Later Agnes Callamard led Al's policy work and research on women's human rights and served as Chef de Cabinet of the Secretary General from 1998 until 2001.

157 Ganzfried: Interview with A.O., 23.01.2015.

158 Ganzfried: Interview with A.O., 23.01.2015.

159 Ganzfried: Interview with A.O., 23.01.2015.

160 Ganzfried: Interview with A.O., 23.01.2015.
} 
interviewee, they started to build "a family's caucus inside the IS,"161 a "pool of researchers who [were] at least gender sensitive, if not feminist."162 Thus, a "triumvirate"163 had organized within the IS by the year 1997 in order to make AI's research more gender sensitive by producing "some groundbreaking reports so that it would set a precedent, some kind of a template for others to do their thing."164

Similarly, the IWN members lobbied to abandon the WOOC rule because "unless Amnesty's sections could become an important voice in their own country, we will never be able to gain full credibility in the eyes of the women's movement."165 As mentioned before, AI finally cancelled the WOOC rule, opening the way for sections to undertake their own research on violations of women's rights in 2001. What my informant labeled the "caucus of feminists and advocates of gender within the IS ${ }^{\text {"166 }}$ was officially known as the Gender Forum. ${ }^{167}$ This forum aimed at providing strategic advice in the implementation of the objectives fixed in AI's strategic plan (the LAP) regarding women's rights. ${ }^{168}$ Curiously, in contrast to the IWN coordinator, who emphasized the pivotal role of the "caucus of feminists," information about the Gender Forum found in archive documents was scarce. The lack of written data indicates that the triumvirate's strategy of making the research more gender sensitive was not straightforward but obviously hidden and not openly communicated.

Evidence indicates that systematized gender analysis in Al's research was difficult. While "the number of IS staff members who have worked on women's issues or are expressing interest in doing so has increased"169 and "women's human rights violations are integrated in the planning and implementation

161 Ganzfried: Interview with A.O., 23.01.2015.

162 Ganzfried: Interview with A.O., 23.01.2015.

163 Ganzfried: Interview with A.O., 23.01.2015.

164 Ganzfried: Interview with A.O., 23.01.2015.

165 Ganzfried: Interview with A.O., 23.01.2015.

166 Ganzfried: Interview with A.O., 23.01.2015.

167 Mentioned as one of the "Institutional measures" Al put in place in chapter 7.1.2.

168 Amnesty International, International Secretariat: International Secretariat Operational Plan 1996-97, 27.09.1996, p.16.

169 Amnesty International, International Secretariat und Amnesty International, International Secretariat: 1997 Meeting of the Intersectional Women's Network (IWN), May 1997, p.7. 
of all campaigns,"170 the IWN criticized that "the manner by which women's rights are reflected in the overall research and actions produced by the Is are inconsistent and unsustainable"171 and that "contextual information that would highlight the gender-based background of human rights violations against women (e.g. cultural issues) is lacking in IS's research."172 Additionally, between 1996 and 2000, the overwhelming majority of individual AI cases continued to prioritize men. The report on the implementation of the LAP revealed that in this period, 3,013 cases focused on men while 192 focused on women. ${ }^{173}$

Concerned about the inconsistency and un-sustainability of how women's rights are reflected in research and actions carried out by the IS, the IWN members stressed the importance of the IEC taking the leading role in making women's rights an integral part of AI's overall work at its third meeting in January $1997 .{ }^{174}$ In their letter to the IEC, the participants in the IWN meeting stressed:

"the overwhelming sense of the meeting is that the IEC must take the lead in ensuring that the movement takes a hard, clear look at the reality of Al's work on women, and develop clear mechanisms of accountability to ensure that the organization is moving systematically to institutionalize and operationalize ICM commitments to increase Al's effective work to promote women's human rights."175

170 Amnesty International, International Secretariat und Amnesty International, International Secretariat: 1997 Meeting of the Intersectional Women's Network (IWN), May 1997, p.7.

171 Amnesty International, International Secretariat und Amnesty International, International Secretariat: 1997 Meeting of the Intersectional Women's Network (IWN), May 1997, p.7.

172 Amnesty International, International Secretariat und Amnesty International, International Secretariat: 1997 Meeting of the Intersectional Women's Network (IWN), May 1997, p.7.

173 Amnesty International, International Secretariat: Final Implementation Report of the Ljubljana Action Plan, 1996-2000, July 2000, p.8.

174 Amnesty International, International Secretariat und Amnesty International, International Secretariat: 1997 Meeting of the Intersectional Women's Network (IWN), May 1997.

175 Amnesty International, International Secretariat und Amnesty International, International Secretariat: 1997 Meeting of the Intersectional Women's Network (IWN), May 1997, p.12. 
Stressing the IWN's pivotal role for the organization's work on women's rights, the participants in the IWN meeting remarked: "our work can only [be] as powerful as our institutionalized support"176 nodding to the IEC. Beside lobbying the IEC, individual sections continued to pressure AI's decision-making organs leading up to the ICM. Such was the case of the Australian section, headed at the time by Kate Gilmore, ${ }^{177}$ who was known as a "women's rights advocate" 178 and future Deputy Secretary General. In fact, the Australian section submitted resolution C1.3.1 to the 1997 ICM (finally accepted as decision 32), calling for a global gender analysis of AI's work.

By 1998, the remaining pressure from the IWN seemed to have borne fruit. In fact, in response to IWN's demands, the IEC declared that "the work on women should not be marginalized or developed as a 'special project"'179 but should be integrated "into the regular work of the IS." ${ }^{180}$ And, in April 1998, the IEC approved the IWN's TORs, ${ }^{181}$ giving the network a formal standing within AI after years of informal existence. Additionally, the IEC finally allocated the resources necessary for a gender audit between 2000 and $2002 .{ }^{182}$ It thereby responded to an old IWN request formulated in resolution B4.4 to the 1995 ICM, which was reiterated in the Australian resolution C1.3.1 to the 1997 ICM. Declaring that it had "recognized the need to consolidate, sustain and institutionalize work on women's rights violations," 183 the IEC "called for the integration of a movement-wide gender-sensitive perspective to AI work." ${ }^{184}$

176 Amnesty International, International Secretariat und Amnesty International, International Secretariat: 1997 Meeting of the Intersectional Women's Network (IWN), May 1997, p.15.

Appointed as Deputy Secretary General around 2001.

178 Kelleher and Bhattacharjya 2013, p.5.

179 Amnesty International, International Executive Committee: IEC Information Bulletin No. 21, January 1998, p.2.

180 Amnesty International, International Executive Committee: IEC Information Bulletin No. 21, January 1998, p.2.

181 Amnesty International, International Executive Committee: IEC Information Bulletin No. 23, April 1998b.

182 Amnesty International, International Executive Committee: IEC Information Bulletin No. 25, October 1998.

183 Amnesty International, International Executive Committee: IEC Information Bulletin No. 27, April 1999, p.26.

184 Amnesty International, International Executive Committee: IEC Information Bulletin No. 27, April 1999, p.26. 
At the same time, female section secretary generals maintained the same pressure during the following ICM. In fact, at the 1999 ICM, the Australian section's secretary general pledged to develop a strategy to fully integrate women's rights into AI's work. Barbara Lochbihler, ${ }^{185}$ secretary general of the German section, expressed the German section's concern about the decline of AI's work on women's rights. At the same time, AIUSA "suggested to create a gender unit in the IS."186

Parallel to this, IWN members pushed to make the organization appoint its first female SG. One of my interviewees explained:

"by $2000,[. .$.$] this pressure on Amnesty was sustained over time, because you$ have a milestone that helps us. So, every five years...so Beijing plus five, Beijing plus ten, we have those milestones to be able to sustain the momentum also within the organization. So, the year 2000 , the milestone, was to have a woman Secretary Ceneral."187

In fact, the nominations of Irene Khan and Kate Gilmore, who was known as a "relatively high-profile figure in women's rights in Australia," ${ }^{188}$ should underscore the organization's willingness and credibility to engage in human rights work on VAW. An interviewee explained: "it was very clear that the board would appoint a Secretary General who would be a woman, so that the public would see at the highest position, at the highest office of Amnesty, we have a public face who is a woman."189

Finally, in the beginning of 2001, the IEC decided to make violence against women the topic of its first global thematic campaign under the mission from 2003 onwards, picking the issue from a list of themes such as the death penalty, children's rights, economic actors, refugee rights, the rights of indigenous people, and land rights and poverty. ${ }^{190}$ In the same year, the ICM en-

185 Before, she was the director of the Women's International League for Peace and Freedom (WILPF).

186 Amnesty International, International Secretariat: Report and Decisions of the 24th International Council of Amnesty International, 21.08.1999, p.16.

187 Ganzfried: Interview with A.O., 23.01.2015.

188 Ganzfried: Interview with B.R., 25.06.2012.

189 Ganzfried: Interview with A.O., 23.01.2015.

190 Amnesty International, International Executive Committee: IEC Information Bulletin 37, July 2001, p.13; Amnesty International, International Secretariat: 25 th International Council Meeting Circular 23 All Human Rights for All: An Integrated Approach to Action, Mandate and Organization, May 2001. 
dorsed the IEC's proposal of a theme campaign on VAW. ${ }^{191}$ As I demonstrate in chapter 8 , selecting the issue of VAW for AI's first global thematic campaign implied "that it gets very high priority in resources,"192 which needed/called for an unprecedented commitment from AI's management. As such, the decision can be interpreted as the fruit of a continuous strategy of parallel networking and analogous framing by female activists and officials.

Summing up, in setting up the IWN, female activists and officials built a strategy to make AI increase its work on issues of VAW which was well adapted to the overall structure of AI. Linking up with like-minded female activists and officials beyond their own national sections proved useful for effectively putting pressure on the organization's decision-making body, as it allowed them to reach out to the whole AI movement and find majorities for their demands at the ICMs. In fact, the strategy of parallel networking first enabled the women and officials of different sections to convince their section delegates to adopt AI's initial decision demanding an increase in the work on women's rights at the 1989 ICM. It then helped them to push sections to submit resolutions raising the same demands to the 1995 ICM and to lobby their ICM section delegates to vote for these resolutions. The female activists and officials lobbying for the adoption of decision 15 at the 1989 ICM and for decision 20 at the 1995 ICM further indicate that they wanted first and foremost an intensification of the organization's work on violations of women's rights within the frame of the mandate. Their strategy of making AI increase its work on violations of women's rights was thus formulated in compliance with the overall policy of the organization.

The strategy of analogous framing was crucial in making AI increase its work on women's rights because it allowed the same activists to compel the majority of the movement to support their claim. Given the long-lasting significance of the state-focused mandate for AI's human rights work and the important debates occurring around the question of whether and to what extent AI should open its mandate to abuses committed by non-state actors, it is worth assuming that a strategy challenging the essence of Al's work would have been less successful. Further, taking advantage of the 1993 UN Conference on Human Rights and the fourth WCW, female activists and officials

191 Amnesty International, International Executive Committee: IEC Information Bulletin 37, July 2001, p.13; Amnesty International, International Secretariat: Action Planning Bulletin November 2001, November 2001. 
who were organized in the IWN successfully pressured the IEC to mind the effective implementation of the ICM decisions (15 ICM 1989 and 20 ICM 1995). In turn, this finally led to the creation of the Special Brief on Women within the IEC and to the appointment of a women's coordinator at the IS. The creation of the position of a women's rights coordinator at the IS in 1995 changed things and made women organized in the IWN adapt their objectives to this achievement. From then on, a triumvirate of women's rights advocates at the IS engaged in making the core of AI's work, namely research, gender sensitive.

Nevertheless, as the continuing pressure of the IWN on the IEC indicates, the strategy of parallel networking remained crucial for female activists and officials. At the same time, the women organized in the IWN maintained their strategy of analogous framing as decision 32 of the 1997 ICM demonstrates. Finally, both of these strategies were important in making AI decide to launch its first long-term thematic campaign under the mission on the issue of VAW. They enabled the effective lobbying of sections, the IEC, and the SG, which in turn allowed women to convince the organization of the necessity to further strengthen its work on violations of women's' rights.

Consequently, female activists played a central role in initiating AI's work on women's rights at the end of the 1980s, and a subsequent bottom-up process of integrating VAW into AI's activities culminated in the SVAW campaign at the beginning of the 2000s. The feminist strategies of parallel networking and analogous framing are key in understanding AI's growing interest in issues of VAW and the associated decision to make VAW the topic of AI's first long-term thematic campaign under the mission. At the same time, as emphasized in chapter 6.2, it is plausible that the growing number of women in management positions at the IS and the supportive SG Pierre Sané also played a positive role. Further, external factors such as the opening of the mandate, the growing international awareness of gender equality stemming from the UN Decade for Women 1975-1985 and the related WCWs, especially the conference in Beijing, and the international women's rights movement challenging AI to expand their mandate to violations of human rights in the private sphere also contributed to the transformation process.

\subsubsection{Al's work on women's rights discussed}

With the strategies of parallel networking and analogous framing, female activists and officials succeeded in making the organization significantly in- 
crease its work on issues of VAW. However, as the present chapter shows, these achievements met with resistance from sections and from within the headquarters. I focus on the debates on the adoption of the decisions directly concerning AI's work on VAW that took place at the ICMs to demonstrate that sections discussed and sometimes opposed these decisions, which were part of the IWN members' strategy of analogous framing. They sometimes also disagreed with the decisions to integrate the issue of FGM into AI's promotional and oppositional work. Nevertheless, resistance against the latter was more important. Then, the section illustrates that integrating a gender perspective into AI's research was not straightforward. In fact, many IS researchers were reluctant to yield to the IWN demands of integrating a gender perspective into the reports produced at the IS.

Figure 5 illustrates that, of all ICM decisions directly concerning AI's work on VAW, those that followed the IWN member's strategy of analogous framing (namely, decision 15 (1989 ICM), decision 20 (1995 IMC), and decision 32 (1997 ICM)) and the decisions demanding the integration of FGM into AI's promotional and oppositional work (decision 6 of the 1995 and 1997 ICM), caused the most debates (left column in figure 5). In contrast, the first ICM decision on FGM, the decision on the UN rapporteur on Women, and decision 9 of the 1995 ICM were not subject to debates (rights column in figure 5).

Figure 5: Debates on the ICM decisions directly concerning AI's work on VAW

Decisions triggering debates among section delegates at the ICM

\begin{tabular}{|c|c|c|c|}
\hline & & Yes & No \\
\hline 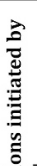 & : & $\begin{array}{l}\text { Decision } 151989 \text { ICM Human rights violations } \\
\text { against women } \\
\text { Decision } 201995 \text { ICM Work on behalf of Women } \\
\text { Decision } 321997 \text { ICM Action on Human Rights } \\
\text { Violations against Women } \\
\text { Decision } 61997 \text { ICM FGM }\end{array}$ & $\begin{array}{l}\text { Decision } 221993 \text { ICM UN Rapporteur on Women } \\
\text { Decision } 91995 \text { ICM Women } \\
\text { Decision } 101993 \text { ICM Female Genital Mutilation }\end{array}$ \\
\hline لֶ. & & $\begin{array}{l}\text { Decision } 61995 \text { ICM Governmental inaction and } \\
\text { FGM }\end{array}$ & \\
\hline
\end{tabular}

Source: my own, based on the reports of the 1989, 1991, 1993, 1995, and 1997 ICMs.

Based on an analysis of the ICM reports, I first highlight the opposition to the IWN members' demand to make AI increase its work on women's rights before illustrating the section's reactions to enlarging AI's mandate with the issue of FGM.

The ICM report reveals that, when discussing decision 15 of the 1989 ICM, "many sections strongly opposed the idea of creating a special category of vic- 
tims of human rights violations, but supported the spirit of the resolution."193 However, given the adoption of decision 15, it is worth assuming that this resistance was limited. Discussions at the 1995 ICM crystallized around the British section's demand for a movement-wide gender analysis of AI's structure and activities (formulated in resolution B4.4). ${ }^{194}$ While the delegates did discuss the usefulness of the other resolutions demanding an increase in AI's work on women's rights, which were finally adopted as decision 20 , they were profoundly divided on resolution B4.4. In fact, a majority of the delegates rejected the resolution, questioning its usefulness and concerned about the costs such a study implied. The Icelandic, Greek, German, and Benin sections, for example, opposed the resolution saying "it was trying to find a problem that did not exist." 195 Referring to the debates around the question of a movement-wide gender analysis, one of the delegates reported that "the quality of the debate [...] was extremely disappointing and showed a lack of understanding of the issues" 196 and a poor understanding of what a gender analysis might imply. ${ }^{197}$

Sections did not only disagree on the content of decision 20. Once it was adopted, sections differed on how the decision should be reflected among AI's strategic priorities over the following years. Various sections questioned the classification of decision 20 as one of LAP's high priority issues. For instance, the Hong Kong section explained that "Amnesty's mandate should be for men, women and children"198 and argued that the disproportional emphasis on women in the LAP "might cause problems in that Amnesty's case-load would not reflect the importance of children."199 Similarly, the Danish and the Swedish sections expressed concern that treating women's rights separately

193 Amnesty International, International Secretariat: Report and Decisions of the 19th International Council of Amnesty International 19-27 August 1989, Dublin, Ireland, 19.08.1989, p.98.

194 See appendix 2 for details on the resolutions.

195 Amnesty International, International Secretariat: 22nd International Council Meeting, 1995, p.132.

196 Watson 1997, p.7.

197 Watson 1997, p.8.

198 Amnesty International, International Secretariat: 22nd International Council Meeting, 1995, p.21.

199 Amnesty International, International Secretariat: 22nd International Council Meeting, 1995, p.21. 
would make them incorrectly appear as "different from men's rights," ${ }^{200}$ or as "different to all people's rights." ${ }^{201}$ In contrast, the Dutch section seemed to have been worried about AI's ability to oppose violations of women's rights: "concentrating too many resources in some situations [of massive human rights violations] might be wasting them; and special emphasis on women could be counterproductive if AI has nothing special to offer." ${ }^{202}$ Further, the Philippines section considered "the women's issues to have been exaggerated" 203 within the LAP.

Sections discussed the demand to increase work on women's' rights with less controversy two years later. While a majority of the section delegates rejected the British resolution for a movement-wide gender policy at the 1995 ICM, they accepted a similar resolution (C1.3.1) from the Australian section that called for "a global assessment for the whole movement of the work accomplished on women's human rights since 1990 "204 at the 1997 ICM. As the report of the 1997 ICM reveals, the formulation of a demand for a gender assessment (rather than a study) of AI's structure and activities rendered the resolution less controversial, finally leading to its acceptance by consensus. This happened despite some sections' initial fears that "expressed concern, given the number of areas covered, that study might be taking precedence over action." 205

Aside from the three subsequent decisions that raised the same demand to the movement, the issue of FGM also caused controversy and triggered some sections' opposition. As section 7.1.1 explained, it took the organization four years to move from the adoption of the first decision (10) at the 1993 ICM to the inclusion of the practice into AI's oppositional work, reflected in decision 6 of the 1997 ICM. This comparatively long process already indicates the

200 Amnesty International, International Secretariat: 22nd International Council Meeting, 1995, p.26.

201 Amnesty International, International Secretariat: 22nd International Council Meeting, 1995, p.26.

202 Amnesty International, International Secretariat: 22nd International Council Meeting, 1995, p.26.

203 Amnesty International, International Secretariat: 22nd International Council Meeting, 1995, p.26.

204 Amnesty International, International Secretariat: 23rd International Council Meeting Report and Decisions, 1997, p.65.

205 Amnesty International, International Secretariat: 23rd International Council Meeting Report and Decisions, 1997, p.65. 
controversial character of the issue. An analysis of the ICM reports shows the content of the debate on the issue among the sections. The delegates approved decision 10 at the 1993 ICM without opposition, urging the IEC to include the issue in a study on governmental inaction and instructing the IEC to present recommendations on how to deal with the issue at the 1995 ICM.

The integration of FGM into AI's promotional work was subject to intensive discussion before and at the 1995 ICM. The contentious nature of the issue becomes evident in the number of different resolutions on it that sections submitted to the 1995 ICM. In addition to an enabling resolution from the IEC, the Netherlands, the Belgium and the Israeli sections submitted resolutions to the 1995 ICM. ${ }^{206}$ While these sections finally withdrew their resolutions in favor of the IEC enabling resolution, the discussions at the ICM concerned three options proposed in the enabling resolution. The first option called for the postponement of the issue to the next ICM. The second one suggested making FGM part of AI's promotional and educational work, and the third, most conservative, option recommended refusing the inclusion of FGM into AI's work. ${ }^{207}$

After long discussions, option two garnered greatest support among the ICM delegates. While some sections suggested amendments to the proposal to make FGM part of AI's promotional work, the final resolution integrating these corrections was finally approved by 33:11 votes to become decision 6. As the ICM report explains, "the debate was divided between those pushing for a major expansion of AI's mandate, and those believing that this whole issue was confusing to the AI mandate." ${ }^{208}$ According to a delegate from the Swiss section, the opposition essentially came from the Northern sections, which claimed that this question would divide the movement between the North and the South. ${ }^{209}$ An interviewee explained the opposition from some of the sections by pointing out that FGM was a taboo that should not be touched upon. $^{210}$

206 See appendix 2 for the details on the resolutions.

207 Amnesty International, International Secretariat: 22nd International Council Meeting, 1995, p.107.

208 Amnesty International, International Secretariat: 22nd International Council Meeting, 1995, p.107.

209 Amnesty International und Internationale Kommission: Procès-verbal de la séance du 28 septembre 1995, 28.09.1995, p.2.

210 Ganzfried: Interview with A.J., 09.03.2012: "Il y a eu des résistances de certaines sections de dire, mais ça c'est un tabou, on ne peut pas toucher à cette problématique.". 
While in 1995 the debate concerned the question of whether AI should or should not integrate FGM into its promotional work, two years later the discussion mainly focused on the way oppositional work on FGM should inform AI's work on non-state actors. Sections presented four different resolutions to the 1997 ICM. This number already indicated the diversity of opinions concerning AI's future work on FGM. In their resolution "Gender Distinction in Genital Mutilation," the Bermuda section, for example, requested not to discriminate between male and female genital mutilation. While the ICM delegates defeated this resolution, they accepted the other three resolutions jointly presented by the Bermuda, the Ivory Coast, and the UK sections. The latter called to test the use of oppositional techniques in the case of FGM and governmental inaction by including the issue in the pilot projects on nonstate actors. ${ }^{211}$ The discussions around the integration of FGM into Al's work that took place between 1993 and 1997 were part of the larger debate AI went through in the 1990s. The latter centered on AI's position concerning cases of human rights violations where the state failed to meet its obligation to prevent the abuse. The debates on how AI should work on the issue of FGM were important because taking action against this practice challenged AI's state-focused mandate, as it also meant taking into account human rights violations perpetrated by individuals.

The analysis of the ICM reports revealed that sections disagreed on the necessity of increasing AI's work on violations of women's rights. Only at the 1997 ICM did a majority of the sections agree upon "the full integration of women's human rights in all areas of Amnesty International's work." 212 The discussions on the adoption of decision 20 at the ICM reveals the existence of internal reticence towards an increase in AI's work on women's rights. However, aside from the resolution calling for a movement-wide Gender Policy at the 1995 ICM, sections did not oppose increasing their work on violations of women's rights. In contrast, the debates on the issue of FGM were more important. They revealed a divide between sections defending Al's work's traditional focus on governments as the primary violator of human rights and others convinced of the necessity to address the problem of state responsibility for inaction in cases of violations of human rights perpetrated in the private sphere.

211 As defined in decision 5 of the 1997 ICM.

212 Amnesty International, International Secretariat: The Decision of the 1997 ICM, 05.01.1998, p.47. 
Evidence from the secondary literature and interviews indicates that resistance to increasing AI's work on women's rights also existed at the IS. Kelleher and Bhattacharjya (2013) point to the negative reactions the Human Rights are Women's Rights campaign received from "conservative members of the IS who were concerned that women's rights activists were trying to highjack Amnesty's voice." ${ }^{213}$ At the same time, the testimony of one of my interviewees reveals the difficulties that plagued the first staff members who integrated a gender perspective into their research:

"Around 1995 [...], I did a report and I had to fight to do a very basic [report]. I used to work on Peru at that time and Ecuador [...]. And I pushed to be able to write a report on women in Peru and the effect on all these women that had been killed by the Shining Path, the Guerrilla group that was in Peru at that time. And it was not easy! They all looked at me oh no I will not do any of that, why? 'You know how many people are disappearing?' I know! It wasn't easy!" 214

Another interviewee mentioned the difficulties the "feminist caucus" at the IS encountered in its efforts to make AI's reports more gender sensitive. She explained that "[The former Research-Policy Coordinator Agnes Callamard] was trying to bring a gender perspective to Amnesty's work and I know she found it very difficult." ${ }^{215}$ For Watson (1997), who used to be a member of AI Australia, the difficulties of integrating a gender perspective into AI had to do with the fact that by this time, the IS research department was dominated by men who "have not been particularly receptive in the past to the criticism that their research strategies have at times been blinkered in ways that mean that women, and the abuses suffered by them, are not readily uncovered."216 For another informant the lack of gender analysis in the researchers' work can be explained with their fear "that once they opened themselves to having a gender analysis in their investigations of what happened to women it would demand a lot of their time, there would be resource implications for them."217

In a nutshell, the analysis of the ICM reports reveals that sections disagreed on the necessity to increase AI's work on issues of VAW. While oppo-

\footnotetext{
213 Kelleher and Bhattacharjya 2013, p.4.

214 Ganzfried: Interview with A.X., 25.06.2012.

215 Ganzfried: Interview by skype with B.H., 18.12.2014.

216 Watson 1997, p.10.

217 Ganzfried: Interview with A.O., 23.01.2015.
} 
sition to the decisions calling for an increase in AI's work on women's rights existed, resistance to AI's position on the issue of FGM was more important as this concern defied AI's mandate. At the same time, the difficulties that female officials at the IS in the 1990s encountered in their efforts to bring a gender perspective into AI's reports indicate that opposition to this new focus existed among the IS staff members. Consequently, AI's work on issues of VAW during the 1990s led to discussions among sections and was criticized from within by the researchers at the IS. However, as I show later, AI's work on VAW encountered much more resistance from sections and from within the IS under the mission.

\subsection{The national levels}

The present chapter illustrates the beginnings of AI's work on issues of violence against women in the Swiss and the German sections. ${ }^{218}$ It highlights that in both sections, female activists initiated this work by forming women's groups focusing on the defense of female prisoners in the early 1980s. Over the years, the women's groups remained the driving force behind the sections' work on issues of VAW. However, women in the two sections organized and proceeded differently. While female activists and officials in the Swiss section seemed to use the strategy of parallel networking, no clear strategy was discernible in the case of the German women's group except for a tendency to focus on influencing decision-making at the international level and maintaining regular exchanges with the IWN. Similar to the section's overall organization of its thematic work, the Swiss section professionalized the work on issues of VAW in the course of the Human Rights are Women's Rights campaign. Meanwhile, in the German section, the women's group continued to be responsible for the majority of the section's work on issues of VAW throughout the 1990s. Further, instead of opposing this initial work, the membership in both sections ignored AI's growing interest in issues of VAW. In contrast, similar to the developments at the international level, the question of state re-

218 In contrast to the Swiss section, where I found many documents on the women's groups themselves, the German section did not grant me access to the documents from the women's group. Therefore, compared to my writing on the Swiss section, the chapter on the German section is less detailed. 
sponsibility for inaction in cases of grave human rights violations committed by non-state actors became an issue of major debate in both sections.

\subsubsection{The Swiss section}

By providing evidence of collective and individual initiatives carried out by female activists concerned about the under-representation of women in the cases AI defended, this section demonstrates that female activists initiated the Swiss section's work on issues of VAW in the early 1980s. Later, I show that the fourth WCW also boosted the section's work on issues of VAW. A demand to the GA to make the section increase its work on women's rights was formulated by a group of female activists and officials during the period leading up to Beijing. In the aftermath of the fourth WCW, the structures involved in issues of VAW developed and female activists and officials finally established a section-wide women's network by 2000 . Thus, in the Swiss case, female activists and officials also used the strategy of parallel networking to make AI increase its work on women's rights at the section level. However, in contrast to the international level, where the IWN had already taken shape in 1989, the formation of a section-wide network was postponed. Then, I highlight that the membership was not generally opposed to work on issues of VAW, as long as the violations did not challenge AI's mandate. In this sense, female activists and officials faced more ignorance than opposition in their efforts to lobby the section.

\subsubsection{First collective and individual initiatives}

The section's work on VAW goes back to the initiatives of female activists in the French and the German parts of Switzerland. ${ }^{219}$ Concerned about the underrepresentation of women in the cases of prisoners of conscience defended by AI, activists formed their own groups and Urgent Action Networks in the beginning of the 1980 s. The latter essentially sought to engage in the release of female prisoners. ${ }^{220}$ The first such group, Réseau d'actions urgentes femmes (Women Urgent Action Network), was comprised of a core group of eight to

\footnotetext{
219 According to one internal document, another urgent action network for women (Frauen-Zielgruppen) existed in Ticino in 1983 (Amnesty International: Frauenkampagne 1991, 1991). However, I could not find further information on this women's urgent action network in the South part of Switzerland.

220 Ganzfried: Interview with B.I., 07.06.2013.
} 
ten women and a pool of about 200 supporters, and was founded in Geneva in $1981 .{ }^{221}$ While the wider network of supporters essentially concentrated on the writing of letters to the relevant authorities, the core group met on a regular basis and organized activities, such as stands for the collection of signatures, or conferences with female victims of political persecution. ${ }^{222}$

The frustration with the invisibility of women in the cases AI defended seems to be the reason for the first collective initiative. In its leaflet, the Geneva Réseau d'actions urgentes femmes explained that "the foundation of such a group was justified by the fact that the public was still ignoring the important number of women prisoners of conscience." ${ }^{223}$ According to them, only $10 \%$ of all Urgent Actions launched within the Swiss section in 1988 concerned women. ${ }^{224}$ According to an interviewee, the group was independent from the rest of the Swiss section finance-wise and activities-wise. ${ }^{225}$

The Réseau d'actions urgentes femmes existed until 1993, when one of the founders of the group left. This withdrawal contributed to the group's difficulties in regrouping and reorganizing its activities. ${ }^{226}$ However, as evidence shows, another women's group formed in Geneva some months later. ${ }^{227} \mathrm{~A}$ second similar collective initiative could be observed in Zurich in the same period. In fact, female activists launched a solidarity women's network called 'Women help politically persecuted women' in $1983 .{ }^{228}$ Like its counterpart in Geneva, the group was composed of a core group of female activists and a wider network of supporters essentially involved in urgent action letter writing.

221 Urgent Actions are one of the methods used by Al. Urgent actions are launched in all cases when a rapid intervention to save a person's life is needed.

Groupe femmes Chêne-bourg: Leaflet on the women's group Chêne-bourg, 14.03.1989. Croupe femmes Chêne-bourg: Leaflet on the women's group Chêne-bourg, 14.03.1989, p.3: "La création d'un tel réseau se justifiait par le fait que le public ignorait et ignore encore trop souvent qu'un grand nombre de prisonniers d'opinion sont en fait des prisonnières.". Croupe femmes Chêne-bourg: Leaflet on the women's group Chêne-bourg, 14.03.1989. Ganzfried: Interview with A.B., 12.04.2012: "Evidemment ça permettait aussi beaucoup de liberté, qui fait que des choses ont pu être faites sans attendre.".

Amnesty International: Schlussbericht zur Reorganisation der Berufs- und Zielgruppen, 09.02.1993.

Amnesty International: Delegiertenversammlung 1994 Postulat F Vorbereitung der Weltfrauenkonferenz in Peking 1995, 30.04.1994. Amnesty International und Frauennetzwerk: Protokoll des Frauennetzwerktreffens vom 21.1.2000, 01.02.2000; Amnesty International: Aufbau eines Solidaritätsnetzes in der Deutschschweiz Frauen helfen politisch verfolgten Frauen, Juni 1983. 
The principle of solidarity seems to have guided the action of these first women's groups. The members' identity as women served as the basis for their engagement for the release of female prisoners. In fact, according to a leaflet, because they faced and continue to be confronted with certain forms of gender-based discrimination and oppression, they felt closer to the women for whom they were writing the urgent actions. ${ }^{229}$ As one of the interviewees explained: "with these women urgent actions, it was about playing with the proximity of women for women." 230 The Women Urgent Action network in Zurich argued for a specific group engaged for the release of women prisoners using the fact that men prisoners of conscience were usually supported by AI professional groups (lawyers, health workers etc.). Meanwhile, female prisoners, often without any professional activity, could not count on a professional solidarity network. ${ }^{231}$

An interviewee explained that women, who were already extremely engaged at the professional level as nurses, social workers, or mothers, initiated these first women's groups. ${ }^{232}$ In contrast to the core group members, the members of the wider network were often just women who wanted to write their letters for other women and "not women who wanted to engage for the UN resolution 1325 or who somehow dealt with a political context." 233 As such, these groups essentially concentrated their public activities at the local level, sometimes collaborating with other local AI groups. At the same time, there was no exchange between the two women's groups until 1988.

229 Croupe femmes Chêne-bourg: Leaflet on the women's group Chêne-bourg, 14.03.1989, p.3: "Notre identité féminine, le fait d'avoir connu et de continuer de connaître certaines formes de discrimination ou d'oppression nous rendent plus proche des femmes pour lesquelles nous écrivons.".

230 Ganzfried: Interview with B.I., 07.06.2013: "avec les actions urgentes socio-professionnelles, c'était de jouer de la proximité des femmes pour des femmes.".

231 Amnesty International: Aufbau eines Solidaritätsnetzes in der Deutschschweiz Frauen helfen politisch verfolgten Frauen, Juni 1983.

232 Ganzfried: Interview with B.I., 07.06.2013: "Par des femmes extrêmement engagées, qui étaient engagées aussi déjà au niveau professionnel, comme infirmière ou comme assistante sociale, ou comme mère de famille aussi.".

233 Ganzfried: Interview mit B.F., 04.04.2012: "Eine Frauengruppe ist früher eine Gruppe gewesen, es sind Frauen gewesen, die zum Beispiel einfach Briefe schreiben wollten zugunsten von Frauen. Das sind nicht Frauen gewesen, die sich für 1325 engagiert haben oder die sich irgendwie mit politischen Kontexten auseinandergesetzt haben. Es sind sehr oft wirklich Frauen gewesen, die wollten einfach ihre Briefe schreiben, aber möglichst für Frauen." 
Then, members of the groups met for the first time at the section's GA. ${ }^{234}$ However, this exchange did not result in other collaborations or activities. Described "as small cells which faced difficulties in expanding,"235 these Women Urgent Action Networks initiated the work on VAW at the Swiss section but their actions had not yet really been recognized by the section. The isolation of the Women Urgent Action Networks began to weaken after the adoption of decision 15 at the 1989 ICM. In fact, the action, launched around the report Women in the Front Line on the $8^{\text {th }}$ of March1991, was the first activity on women's rights organized by the secretariat of the Swiss section in collaboration with the women's group in Zurich. ${ }^{236}$ Women's rights activists affiliated to the Women Urgent Action Network Zurich used the occasion to widen the spectrum of their activities by calling for new members to build up a bigger women's group. ${ }^{237}$ The women's group in Zurich reiterated their call for new members and an action network when launching the women's day action a year later. ${ }^{238}$

Independent of the collective activities of the Women Urgent Action Networks in Geneva and Zurich and the 1991 action, individual AI female activists initiated activities on the issue of VAW on their own. For instance, they focused on violations of women's rights in specific country projects they were in charge of. ${ }^{239}$ Others discussed the issue in their local AI group. An interviewee explained the significance of these individual initiatives:

"At the Swiss section, we also have women who had been engaged since the beginning of Al. Some of them at the Swiss section have always prioritized women's rights even before the movement decided to make it a top priority; they organized fantastic actions and campaigns with effective people mobilization." 240

234 Groupe femmes Chêne-bourg: Procès-verbal du 3 décembre 1987, 03.12.1987; Groupe femmes Chêne-bourg: Procès-verbal du 7 avril 1988, 07.04.1988.

235 Ganzfried: Interview with A.J., 09.03.2012: "C'était comme des petits noyaux qui avait un petit peu de la peine à essaimer.".

236 Amnesty International: Frauenkampagne 1991, 1991.

237 Amnesty International: Frauenkampagne 1991, 1991.

238 Amnesty International: Frauenkampagne 1992 Aktionsanleitung, 08.03.1992.

239 Ganzfried: Interview mit B.F., 04.04.2012: "Ich habe einfach im Rahmen von meiner Arbeit immer geschaut, dass ich irgendwie möglichst viele Frauen auch in diese Projekte hineinnehmen konnte.".

240 Ganzfried: Interview with A.I., 26.09.2012: "On a aussi au niveau d'Al des femmes qui sont engagées depuis quasi les débuts d'Al. [...] p. ex. Alba Viotto [...]; des femmes incroyables qui 
Another interviewee mentioned the exposition of Rwandan artists meant to call attention to the women rights violations that occurred during the genocide as another example of individual initiatives from female activists. ${ }^{241}$ The first collaborations between members of the women's group and staff at the secretariat emerged around the same time, and individual officials started to pay attention to the sex of the prisoners of conscience they were defending. An interviewee explained that she "relied upon these volunteers of the women's [group] to have their know-how about how to sell this question or integrate this women's issue into the campaign ['500 Years of the Discovery of Latin America and Its Impact on Indigenous People']." ${ }^{242}$ She further highlighted that she also attempted "to have a woman when we had our famous illustrative cases and not only have Tibetan monks." 243

Summing up, female activists concerned about the invisibility of women in AI's case work initiated the section's work on VAW in the 1980s. They organized in the so-called Women Urgent Action Networks, which were based on the idea of solidarity among women and took action for the release of women prisoners. In addition to the Women's Urgent Action Networks in Zurich and Geneva, which functioned independently from the secretariat, individual women activists highlighted violations of women's rights with their own specific activities, and individual officials began to consider women's rights within the section's campaign work. A first section-wide action on the issues of VAW was organized in connection with the launch of the report Women in the Front Line. As I show in the next section, the isolation of the work on women's rights began to evolve with the preparation of the 1995 campaign Human Rights are Women's Rights.

ont toujours défendu les droits des femmes avant que le mouvement décide de les mettre en top priorité et qui ont organisé des actions et des campagnes magnifiques capables de mobiliser les gens.".

241 Ganzfried: Interview with A.J., 09.03.2012: "Des femmes comme cette Alba Viotto. Elle a par exemple organisé une exposition d'artiste sur le Rwanda.".

242 Ganzfried: Interview with A.J., 09.03.2012: "Je m’appuyais sur ces bénévoles de ce réseau femme pour avoir un peu leur know-how comment vendre un peu la question, intégrer cette problématique femme dans la campagne [500 ans de découverte de l'Amérique latine sur les peuples indigènes].".

243 Ganzfried: Interview with A.J., 09.03.2012: "On a toujours essayé de voir quand on avait nos fameux cas d'appel illustratifs d'avoir une femme. On n'avait pas que des moines tibétains.". 


\subsubsection{A women's network emerges}

The movement-wide mobilization around AI's participation in Beijing and the 1995 campaign also affected the Swiss section. Female activists and officials actively started to pressure the section to increase its efforts in the area of women's rights in the period preceding the Beijing conference. In fact, concerned about the delayed start of the preparation for the fourth WCW, a group of female activists submitted a postulate to the 1994 Annual Assembly demanding: "instead of waiting for [international] action plans, the section should have already committed to an intensified engagement for women and tried to reinforce the women's groups by now." ${ }^{244}$ In the postulate they further called upon "the Swiss section to stress women's human rights on the occasion of the Beijing conference." 245

Under the name Frauen in Aktion - Frauen in Gefahr, the section participated in the movement-wide Human Rights are Women's Rights campaign in 1995. Many activists and officials were strongly involved in the preparation for and organization of this campaign, which, according to an informant, enhanced the members' awareness of the importance of integrating the work on women's rights into AI's overall work. In view of the 1995 campaign preparation, both designated staff members and the women's groups were responsible for the section's work on women's rights for the first time. Concretely, the people involved in the preparation and coordination of the 1995 campaign Frauen in Aktion - Frauen in Gefahr included a voluntary coordinator (called Frauenkoordinatorin), based at the secretariat and in charge of coordinating activities between the secretariat and the women's groups in Geneva and Wil, ${ }^{246}$ and two female officials responsible for campaigning and action. ${ }^{247}$

244 Amnesty International: Delegiertenversammlung 1994 Postulat F Vorbereitung der Weltfrauenkonferenz in Peking 1995, 30.04.1994, p.1: "Statt Aktionspläne abzuwarten, sollte sich die Sektion schon jetzt zu einem intensiveren Einsatz für Frauen bekennen und bereits jetzt versuchen, die BZ-Gruppen Frauen zu stärken.".

245 Amnesty International: Delegiertenversammlung 1994 Postulat F Vorbereitung der Weltfrauenkonferenz in Peking 1995, 30.04.1994, p.1: "Die Schweizer Sektion [...] setzt anlässlich der Konferenz einen sichtbaren Schwerpunkt für die Menschenrechte von Frauen.".

246 In fact, an analysis of the archival materials sheds light on the formation of a women's group in Wil, which apparently replaced the former Women Urgent Action Network Zurich.

247 Amnesty International: Protokoll der Sitzung vom 3.11.1994 im Al-Sekretariat, Bern Themen: Peking, Frauenkampagne, Stärkung der Frauengruppen, 03.11.1994; Amnesty International: Sitzung in Zürich vom 15. Dezember 1994 zur Vorbereitung der 
Boosted by the movement-wide activities surrounding the 1995 Beijing conference and the campaign, the Swiss section saw the number of women's groups increase in the following years. A new women's group was founded in Lausanne in August 1998. ${ }^{248}$ Initiated by the secretariat, another women's group was established in Bern around the same time. ${ }^{249}$ The Frauen Urgent Action Netz und Frauengruppe Zurich was relaunched as a formal women's group the same year. A new women's group was founded in Geneva in 2000. ${ }^{250}$ Further, a so-called Kogruppe formed in October 1999. ${ }^{251}$ The Kogruppe was an advisory group with the objective of acquiring knowledge on women's rights issues and providing sections with advice on these issues. An interviewee described its role as "similar to other specialist groups that were experts in the export of weapons or death penalty." ${ }^{252}$

As far as the secretariat was concerned, by 2000 , an intern there was given the task of coordinating the activities of the different women's groups, ${ }^{253}$ and a staff member was assigned to work on women's rights. ${ }^{254}$ Thus, by the end of the 1990s, female activists and officials were organized in four local women's groups and a Kogruppe, and two persons were in charge of the work on women's rights issues at the secretariat.

The formation of a section-wide network happened simultaneously and also benefited from the exchange with the IWN. While I could not find any evidence of regular contacts with the IWN, there must have been exchanges at particular points. On a visit to the Swiss section in October 1999, the IWN coordinator met with women activists and stressed the importance of organizing a women's network within the Swiss section: "It is pivotal to know each

Frauenkampagne und Peking, 15.12.1994; Amnesty International: Protokoll der Sitzung vom 15. Dezember 1994 zur Vorbereitung der Frauenkampagne und Peking, 15.12.1994.

248 Amnesty International und Frauennetzwerk: Protokoll des Frauennetzwerktreffens vom 21.1.2000, 01.02.2000.

249 Amnesty International: Reconnaissance d'un groupe Amnesty en formation, 21.09.1999; Frauennetzwerk: Le réseau femmes se présente, ca. 2000.

250 Frauennetzwerk: Le réseau femmes se présente, ca. 2000.

251 Amnesty International und Frauennetzwerk: Protokoll des Frauennetzwerktreffens vom 21.1.2000, 01.02.2000.

252 Ganzfried: Interview by Skype with A.T., 12.09.2012.

253 Amnesty International: Protokoll der Sitzung Aufbauprojekt Kogruppe Frauen, 20.10.1999.

254 Frauennetzwerk: Le réseau femmes se présente, ca. 2000. 
other and to enrich mutually. The women's work does not have to be limited to a small group acting in a corner; the women's issue has to go through the whole section." ${ }^{255}$ The strategy of building a section-wide women's network in order to bring forward the issue of women's rights became evident in the invitation to a first network meeting in January 2000, where the coordinator explained: "It is also important [...] by the establishment of a strong network to build a common ground for leading the battle for the defense of women's rights worldwide but also within AI well and successfully." ${ }^{256}$ At a first meeting in January 2000, the members emphasized their conviction that a women's network was extremely necessary to strengthen, link, and keep the women's rights movement updated. ${ }^{257}$ The network members met again in April and June of the same year. There, they once again stressed the importance of "a continuing presence with regards to the secretariat so that women's rights remain an issue." 258 One of the first actions of the network consisted in an intervention at the section's GA in 2000 , which called the delegates' attention to the activities of the various women's groups. According to the network members, the intervention was successful as it reinforced the participants' impression of the growing significance of the women's network for the section's work. ${ }^{259}$

Summing up, the structures involved in the section's work on issues of VAW evolved from two independently acting urgent action networks in the 1980 into a section-wide women's network composed of activist groups, an

255 Croupe Al femmes - Lausanne: Procès-verbal de la réunion du groupe Amnesty Femmes - Lausanne: 25 Octobre 1999, 30.10.1999.

256 Amnesty International: Einladung zum Frauennetzwerktreffen, 07.12.1999, p.1: "So ist es auch wichtig [...] durch das Bilden eines starken Netzwerkes, eine gemeinsame Basis aufzubauen, damit der Kampf-es ist tatsächlich noch immer ein Kampf-für die Verteidigung der Frauenrechte weltweit aber auch innerhalb von Al, erfolgreich und gut geführt werden kann.".

257 Amnesty International und Frauennetzwerk: Protokoll des Frauennetzwerktreffens vom 21.1.2000, 01.02.2000.

258 Amnesty International und Frauennetzwerk: Protokoll des Frauennetzwerktreffens vom 20. Juni 2000, 20.06.2000, p.3: "eine anhaltende Präsenz gegenüber dem Sekretariat, damit Frauenrechte ein Thema bleiben.".

259 Amnesty International: Einladung zum Frauennetzwerktreffen 19. April 2000, March 2000, p.1: "Die DV Besucher/innen konnten der Erfahrung nicht ausweichen, dass sich innerhalb Al ein ziemlich aktives Frauennetzwerk ausbreitet, das über kurz oder besser lang die Aktivitäten der Sektion beeinflussen wird.". 
advisory group and staff members in the late 1990s. Female activists and officials began to organize collectively with the aim of making their sections increase the work on women's rights issues during the Beijing preparation period. The formation of a section-wide network of women's activists and officials had become a strategy meant to strengthen the section's work on violations of women's rights by 2000 . Thus, parallel networking also was a strategy female activists and officials within the Swiss section employed to make the section increase its work on women's rights. However, compared to the developments at the international level, where female activists had already gathered in the IWN by 1991, this strategy only became evident after the 1995 campaign. Further, in contrast to other sections, such as the US, the Canadian or the British one, where female activists and officials who were organized in the IWN lobbied their sections in order to influence decision-making at the ICM, I could not find any evidence of a female activists' and officials' attempt to influence AI's general agenda. It seems that female activists and officials strategizing in a section-wide women's network focused on the work of their own section.

\subsubsection{Ignorance rather than opposition}

The present section shows that the work on violations of women's rights faced the Swiss section's disinterest, rather than opposition during the 1990s. In contrast to the developments at the international level, no sign of explicit resistance to the work on this issue is detectable at the Swiss section during this decade. Instead, given that almost 20 years passed between the foundation of the first Urgent Action Network in Geneva in 1981 and the establishment of a section-wide women's network by 2000 , the membership must have simply ignored this kind of work for many years. Similar to what I emphasized at the international level, the question of how AI should work on the issue of state responsibility for inaction - and, relatedly, AI's approach to FGM - was much more controversial.

The section's indifference towards women's rights issues became visible in its reaction to the first intersectional meeting of the IWN that was organized in Geneva in 1991. An interviewee, explains that the secretariat was initially unwilling to help the US section to organize the event. She interpreted the refusal as a form of opposition to the initiative stating: "for example, when the Swiss section replied to the US section that it was not able to do it, [...] 
it was a form of resistance, which is important." ${ }^{260}$ In contrast, rather than resistance, the statements of other interviewees demonstrate the disinterest and ignorance of large parts of the membership. An interviewee explained that of "those engaged in the issue of women's rights, a lot had to plough through a layer of boredom and disinterest." ${ }^{261}$ Another informant stated: "I have never felt any resistance to say 'but why are you choosing this women's issue at AI?"'262 Another interviewee agreed that there was no formal opposition forbidding the formation of women's groups. However, she pointed to the section's lack of support and encouragement. ${ }^{263}$ And for another interviewee, the establishment of the women's group and the efforts to raise awareness of women's rights within AICH was quite a battle. ${ }^{264}$

The membership's disinterest also became visible in the women's groups' activities. Throughout the 1990s, the main structures that engaged in activities concerning violations of women's rights were women's groups. As the example of the women's group Bern shows, only a few other activists participated in activities organized by women's groups. In fact, the minutes of the meetings of the women's group Bern reveal that "the AI internal participation was extremely lean and disappointing for us." ${ }^{265}$ The members of the women's group were very disappointed by the officials' lack of enthusiasm and idealism as well as by their general absence from the events organized by the women's group. $^{266}$

260 Ganzfried: Interview with A.B., 12.04.2012: "Quand la section Suisse répond par exemple à la section américaine qu'elle ne peut pas le faire, sans consulter...'est une forme de résistance qui est importante.".

261 Ganzfried: Interview by Skype with A.T., 12.09.2012: "Vermutlich haben sich diejenigen, die sich da sehr engagiert haben dafür, dass Al das aufnimmt, mehr durch so eine Schicht von Langeweile und Desinteresse durchackern müssen, das ist meine Vermutung.".

262 Ganzfried: Interview with A.J., 09.03.2012: "'ai jamais ressenti de résistance de dire 'mais pourquoi vous choisissez cette problématique femme au sein d'Al?".

263 Ganzfried: Interview with A. B., 12.04.2012: "Il n'y avait pas, disons, d'opposition formelle. Moi je n'ai jamais trouvé quelque chose d'écrit qui interdisait la création de groupes femme. Mais il n'y avait pas, en tout cas, de soutien ni d'encouragement, à cette époque-là.."

264 Ganzfried: Interview with B.K., 16.05.2013: "[Die Etablierung der Frauengruppe und die Förderung von Frauenrechten innerhalb Al] ist ein ziemlicher Krampf gewesen.".

265 Frauengruppe Bern: Protokoll der Monatssitzung November der Frauengruppe Bern, 25.11.1999, p.1: "Al-interne Beteiligung war äusserst mager, enttäuschend für uns.".

266 Frauengruppe Bern: Protokoll der Monatssitzung November der Frauengruppe Bern, 25.11.1999, p.1: "Bemerkung zu Al-Sekretariatsleuten: Es wird bemängelt, dass kein En- 
Thus, the membership's reaction to the work on issues of VAW was generally not opposition but disinterest. An interviewee interpreted this as a manifestation of members' fear of the mandate's dissolution or of their lack of knowledge about how to work on violations of women's rights, in the aftermath of long years of engagement against any abuses of political and civil rights, regardless of the victim's identity. ${ }^{267}$ For another interviewee, the lack of interest in the issue was mainly a consequence of the field from which AI developed, which she qualified as "somehow closely related - in a rather problematic way - to the sex-appeal of the political combatant." ${ }^{268}$ The same interviewee qualified some of the very engaged people within $\mathrm{AI}$ as "kind of exciting guys, half Che Guevaras." ${ }^{269}$ According to her, parts of AI's work had always somehow been the search for sex-appeal, thereby making women's rights issues seem much less exciting. ${ }^{270}$ However, she did not interpret the absence of interest as a sign of misogyny. ${ }^{271}$

While there had been no resistance to the work on issues of women's rights in the 1990s, archival material indicates that the opening of the mandate to states' responsibility for inaction and the related issue of FGM caused discussions among the members of the Swiss section. ${ }^{272}$ Members disagreed on the question of whether and to what extent AI should combat violations of human rights in the private sphere. For example, in a comment to the secretariat, the members of the women's group Zurich raised concerns about the inclusion of human rights violations in the private sphere, with which

thusiasmus und Idealismus auf ihrer Seite spürbar ist. Selten kommen Echos von ihnen, da sie sich auch selten an Anlässen zeigen. Finden wir schade.".

267 Ganzfried: Interview mit B.F., 04.04.2012: "Aber mehr zum Teil auch aus Unkenntnis. Oder das Bewusstsein ist einfach von diesen langen Jahren wo man es nicht gemacht hat noch so stark, dass doch eigentlich von Folter, von Verschwinden lassen, von aussergerichtlichen Tötungen. Alle sind betroffen, wieso muss man jetzt das irgendwie fokussieren aufeine Cruppe?".

268 Ganzfried: Interview by Skype with A.T., 12.09.2012: "Also es war eigentlich mehr so, dass das Interesse vielleicht bei einigen nicht so gross war. Wissen Sie, das Feld, aus dem Al gewachsen ist, das ist eine Sache die irgendwie wahnsinnig viel und auch irgendwie auf ein bisschen fragwürdige Art und Weise mit dem Sexappeal des politischen Kämpfers zu tun hat.".

269 Ganzfried: Interview by Skype with A.T., 12.09.2012: "Leute, die sich auch sehr engagiert haben und so aufregende Typen waren so halbe Che Guevaras. Und dann sind Frauen irgendetwas.".

270 Ganzfried: Interview by Skype with A.T., 12.09.2012.

271 Ganzfried: Interview by Skype with A.T., 12.09.2012: "Ich sehe da auch keine grosse Frauenfeindlichkeit dem Thema gegenüber.".

272 Ganzfried: Interview by Skype with A.T., 12.09.2012. 
AI would certainly be overwhelmed. According to the author, an engagement against human rights violations perpetrated by private persons in individual cases was not feasible for practical and technical reasons. ${ }^{273}$ In another statement, a female activist argued that it is important to include state inaction in the mandate in order to effectively protect women from violence. ${ }^{274}$

Relatedly, members disagreed on how to integrate FGM into AI's work. Critical voices argued that working on FGM would mean engaging in an issue that does not concern them ${ }^{275}$ and others reasoned that NGOs, such as UNICEF, that were specialized in the issue were better placed and able to combat this specific women's rights violation than AI. ${ }^{276}$

Consequently, the work on VAW as covered by the mandate - reflected in the report Women in the Front Line and the 1995 campaign Frauen in AktionFrauen in Gefahr as well as the formation of specific women's groups and the creation of a women's network - was not seen as controversial. The disinterest observed at the Swiss section contrasts with the findings about the IS, where the feminist caucus regularly faced with criticism and resistance. Nevertheless, as the discussion around the work on FGM illustrates, cases of VAW became subject to debate when they challenged AI's state-focused mandate.

\subsubsection{The German section}

This section illustrates that by forming the Sektionsarbeitskreis Menschenrechtsverletzungen an Frauen (MaF) female activists initiated the German section's work on women's rights in the 1980s. Similar to the Swiss section, the MaF initially focused on cases of female prisoners. The section continues by highlighting that the MaF carried out the majority of its work on issues of

273 Leiterin Zielgruppe Frauen: Stellungnahme zur Frage der Mandatserweiterung betreffend "Governmental inaction", 05.12.1994.

274 C.: Persönliche Stellungnahme zur Mandatserweiterung "State inaction”, 23.11.1994.

275 Ganzfried: Interview with B.N., 06.06.2013: "Et bien, justement, je me rappelle, justement, sur les mutilations infantiles, les mutilations des jeunes filles. Ça je me rappelle, il y en a qui [disaient] 'oui, mais c'est s'occuper de choses qui ne nous regardent pas'.".

276 Ganzfried: Interview with A.P., 24.06.2013: "Ein ganz typisches Beispiel ist natürlich Frauenbeschneidung gewesen, wo ja UNICEF sich ganz stark macht dafür, wo man irgendwann sagen musste, ja sollen wir auch noch so viele Ressourcen gleichzeitig in diesem Ausmass bringen?'Obwohl wir es thematisiert haben, aber ich denke es ist auch sinnvoll, dass man sagt 'also da gibt es ja eine NCO die das ganz gross bringt, also müssen wir jetzt nicht auch noch nebendran ganz ganz gross sein?'.". 
VAW as a Fachgruppe (expert group) and remained a driving force behind the section's work on violations of women's rights throughout the 1990s. The section further demonstrates that the MaF became involved in policy-making when the movement was about to make its first decision calling for an increase in Al's work on women's rights in the late 1980. The Fachgruppe then demanded the submission of other resolutions about the movement's work on issues of VAW to the ICM in the 1990s. Further, I also show that the MaF was a particularly active part of the IWN at this moment.

However, in contrast to the Swiss section, the German section did not establish a specific position for work on women's rights at the Secretariat. Instead, women's rights violations were included in the work on asylum and refugees, which at this time was the only thematic human rights issue the secretariat worked on. ${ }^{277}$ Then, I briefly describe that the section's reaction towards work on women's rights was mainly disinterest and not resistance. In contrast, just like in the Swiss section, the question of state responsibility for inaction in cases of grave human rights violations committed by non-state actors was an issue of major debate among members.

\subsubsection{Sektionsarbeitskreis Menschenrechtsverletzungen an Frauen}

Female activists initiated the work on women's rights in the German section in the 1980s. The Sektionsarbeitskreis Menschenrechtsverletzungen an Frauen $(\mathrm{MaF})^{278}$ formed in 1984 and was formally recognized by the section in $1987 .^{279}$ An article in the internal magazine ai-info reveals that the foundation of the MaF goes back to "the need of several AI activists to conduct an in-depth analysis of the different situations of women confronted with state measures and to highlight potential analogies." 280 According to an interviewee, "it was very much this working group (MaF) [that pushed the issue of women's rights

\footnotetext{
277 See chapter 6.3.2.2.

278 In English: Working Group Violations of Human Rights of Women.

279 Deile et al. 2015.

280 Amnesty International Sektion Bundesrepublik Deutschland: Artikel im ai info 6/86, Juni 1986, p.10: "Es besteht bei den Mitgliedern das Bedürfnis, die verschiedenen Situationen von Frauen, die staatlichen Massnahmen ausgesetzt sind, inhaltlich tiefergehend zu untersuchen und eventuelle Parallelen aufzuzeigen.".
} 
at the German section] ${ }^{281}$ in the early years. Similar to other Sektionsarbeitskreise, the MaF members were dispersed all over the country and initially only met at the biannual Bezirkssprecherkonferenzen or during seminars. The MaF thus resembled a network linking female activists from all over the section more than it resembled a local AI group.

Like its Swiss counterpart, the group focused on female prisoners and gender-specific forms of violence and persecution in its early years. ${ }^{282}$ In contrast to the Swiss section, where the women's group used the wording "women's rights" to refer to the rights it was engaged with, the MaF explicitly defined its engagement as action against "violations of human rights of women." An interviewee explained the choice of this wording: "In our opinion, there are no women's rights but human rights, and these human rights are particularly often violated in the case of women. [...] These are human rights valid for women. That is why we do not like the phrase 'women's rights'."283

Raising AI members' awareness as well as that of a larger public had been at the core of the group's engagement in the 1980s. Members of the MaF frequently published articles on the issue of politically persecuted women in the ai-info. ${ }^{284}$ Yet, as the following example illustrates, the MaF's activities went beyond promoting the issue within the section. In fact, one of the most important actions the MaF was involved in was the submission of a motion on gender-specific persecution and violence women prisoners were victims of to the Deutsche Bundestag (the German Parliament) in 1988, in cooperation

281 Ganzfried: Interview by phone with B.E., 06.03.2015: "Das war ganz stark diese Arbeitsgruppe [die sich für das Thema Frauenrechte innerhalb der Deutschen Sektion stark gemacht hat].".

282 Amnesty International Sektion Bundesrepublik Deutschland: Artikel im ai info 6/86, Juni 1986.

283 Ganzfried: Interview by phone with A.Y., 09.01.2015: "Wir sind der Ansicht, es gibt keine Frauenrechte, sondern es gibt Menschenrechte und die Menschenrechte werden bei Frauen besonders oft verletzt. [...] Es sind Menschenrechte, die für Frauen gelten, deshalb finden wir das Wort 'Frauenrechte' nicht so gut.".

284 Amnesty International Sektion Bundesrepublik Deutschland: Artikel im ai-info 3/1987, März 1987; Amnesty International Sektion Bundesrepublik Deutschland: Artikel im aiinfo 4/1988, April 1988; Amnesty International Sektion Bundesrepublik Deutschland: Artikel im ai-info 3/1987, März 1987; Amnesty International Sektion Bundesrepublik Deutschland: Mehrere Artikel im ai-intern 3/1989 zum Thema "Frauen und Menschenrechte“, März 1989. 
with 63 women from all congressional parties. ${ }^{285}$ According to an official, "this was one of the first initiatives exclusively introduced by women beyond the congressional parties in the German Parliament."286

\subsubsection{The MaF's successful attempts to influence decision-making}

In addition to internal and public awareness-raising activities on violations of women's civil and political rights, the MaF became involved in policy-making at a relative early stage. In fact, the minutes of the 1988 and the 1989 meetings of the section's GA illustrate the existence of a motion calling on the section to increase its research on human rights violations against women. They also document the section's decision to submit resolution B14 to the 1989 ICM, which was subsequently accepted as decision 15. Even though these documents do not identify the author of the motion, ${ }^{287}$ given the MaF's prominent role in the section's work on women's rights at that time and in the following years, it is worth assuming that female activists organized in the MaF were among the initiators of the demand. The MaF continued to influence decision-making at the international level by submitting a motion to the $1992 \mathrm{GA}$ which the section subsequently submitted to the 1993 ICM as resolution B37, asking the organization to support the establishment of a UN Special Rapporteur on Violence Against Women and to capitalize on the fourth WCW by organizing a campaign on women's rights. ${ }^{288}$

Similar to the IWN, the MaF took advantage of the 1993 UN Human Rights Conference in Vienna "[...] to express again long-standing demands for the protection of women from women-specific persecution at the international level." ${ }^{289}$ In the same document, the MaF spokesperson invited AI "to take

285 Amnesty International Sektion Bundesrepublik Deutschland: Artikel im ai-info 4/1988, April 1988.

286 Ganzfried: Interview by phone with B.U., 13.02.2015: "Das war eine der ersten Initiativen im deutschen Bundestag, die NUR von Frauen angestossen wurde und zwar Fraktionsübergreifend.".

287 Amnesty International Sektion Bundesrepublik Deutschland: Protokoll der 23. Jahresversammlung vom 21.5. bis 23.5.1988 in Wuppertal, 24.05.1988; Amnesty International Sektion Bundesrepublik Deutschland: Protokoll der Jahresversammlung 1989 Oldenburg 13. bis 15. Mai 1989, 15.05.1989.

288 Amnesty International Sektion Bundesrepublik Deutschland: Antrag an die Jahresversammlung 1992 der AK-Menschenrechtsverletzungen an Frauen, 19.03.1992.

289 Reichinger und Sektionsarbeitskreis Menschenrechtsverletzungen an Frauen: Die Weltmenschrechtskonferenz in Wien - eine Bilanz aus frauenspezifischer Sicht, 30.11.1993, p.1: "Auch unser Arbeitskreis nahm diese Konferenz zum Anlass, erneut 
the appeals calling for an increased focus on women's human rights within the human rights work to heart." ${ }^{290}$

In addition to the MaF's attempts to influence decision-making at the international level by submitting motions to the GAs, the group must have also been a particularly active part of the IWN. In fact, the second meeting of the IWN in Bonn goes back to the initiative of the German section's IWN member, who was also the IWN interim coordinator before the appointment of the IWN coordinator at the IS in 1995. Further, the MaF played an important role in the section's activities related to the 1995 campaign. In an outline of the focus of the 1995 campaign sent to the section, the MaF suggested "[...] to call the groups to end the thematic marginalization of violations of human rights on women and to stop always consulting the same public (the Women's movement, church women, union women, women in parliament, etc.)." ${ }^{291}$ In the same document, the MaF further recommended that the country coordination groups work on violations of women's rights in their respective countries. The MaF further argued that international developments were increasingly overtaking AI and "urged that we in our organization handle the new facts regarding the development of human rights in a constructive way, not only to remain modern, but to continue being relevant!"292 It demanded that the section should take the opportunity presented by the campaign to initiate an internal discussion about the section's conception of human rights.

Additionally, the MaF pushed the section to participate in the Germanwide NGO activities in preparation for Beijing by suggesting that the EC

langjährige Forderungen gegenüber internationalen Ebenen zum Schutz von Frauen vor frauenspezifischer Verfolgung vorzubringen."

290 Reichinger und Sektionsarbeitskreis Menschenrechtsverletzungen an Frauen: Die Weltmenschrechtskonferenz in Wien - eine Bilanz aus frauenspezifischer Sicht, 30.11.1993, p.3: "Auch ai sollte sich die Appelle, Frauenmenschenrechte in der Menschenrechtsarbeit mehr Gewicht zu geben, zu Herzen nehmen.".

291 Amnesty International Sektion Bundesrepublik Deutschland: Letter from Frauke Marohn from the MAF-Sektions-AK, 1994, p.3: "[...], wollen wir die Gruppen auffordern, die thematische Marginalisierung von Menschenrechtsverletzungen an Frauen zu beenden und sich nicht immer wieder an immer dieselben Adressaten (Frauenbewegung, Kirchenfrauen, Gewerkschaftsfrauen, Frauen im Bundestag etc.) zu wenden.".

292 Amnesty International Sektion Bundesrepublik Deutschland: Aufriss des MAFSektions-AK's zu einer internationalen ai-Kampagne gegen Menschenrechtsverletzungen an Frauen 1995, 32.3.1994, p.3-4: "Wir halten es darum für dringend geboten, dass wir in unserer Organisation konstruktiv mit den neuen Tatsachen der MR-Entwicklung umgehen, nicht allein, um modern zu sein, sondern um sachgerecht zu bleiben!". 
send a member of their group as the AI representative to the NGO coalition NGO-Frauenforum. ${ }^{293}$ At the same time, various letters to the German delegation illustrate the MaF's involvement in the section's lobbying activities for the integration of women's civil and political rights into the WCW's final document. 294

As far as the section's campaign activities were concerned, while local and thematic groups participated in the campaign, the MaF realized the majority of the thematic work related to the campaign in its capacity as an expert group. In contrast to the Swiss section, the German section had not established any specific position for the work on women's rights issues at the Secretariat by the time of the 1995 campaign. Instead, some officials working in the department on Länder Themen und Asyl (country-related issues and asylum) focused on issues of women's rights because female refugees were considered particularly vulnerable persons, who often fled from gender-based human rights violations. ${ }^{295}$

The lack of archival materials for the period between 1996 and 2000 does not allow me to provide more details about the German section's work on issues of VAW or about the MaF in the post-Beijing period. The only evidence I collected is some information about the dissolution of the MaF during this period. ${ }^{296}$ However, as I show in chapter 8.2.2, the group continued to play a significant role in the implementation of the SVAW campaign within the German section in a new composition.

Summing up, like in the Swiss section, women initiated the German section's work on issues of VAW in the 1980s. By setting up a thematic Sektion-

293 Amnesty International Sektion Bundesrepublik Deutschland: Letter from the Sektions-Arbeitskreis Menschenrechtsverletzungen to the Executive Committee, 24.06.1994.

294 Amnesty International Sektion Bundesrepublik Deutschland: Protokoll Lobbygespräch im Auswärtigen Amt am 22.3.1995, 13.05.1995.

295 Ganzfried: Interview with B.T., 15.04.2015. The section's specific focus on the rights of female refugees also becomes evident in the publication Frauen im Blickpunkt (1991), which included a chapter on female refugees and on the protection of persecuted women in Cermany, and in the report Frauen in Aktion - Frauen in Gefahr (1995), which specifically focused on female asylum seekers in Cermany (Amnesty International Sektion Bundesrepublik Deutschland 1991; Amnesty International, Sektion Bundesrepublik Deutschland 1995).

296 "The preceding group, which had been in place since the 1980s, somehow petered out" (Ganzfried: Interview by phone with A.Y., 09.01.2015). 
sarbeitskreis, with members dispersed all over the country, female activists organized nationally within the German section with the aim of raising the section's awareness of violations of the human rights of women. The MaF got involved in decision-making immediately after its formal recognition by the section in 1987. It initiated several motions to the section's GA demanding the submission of resolutions relevant to AI's work on issues of VAW to the ICM. As an expert group, the MaF carried out most of the section's work on violations of women's rights before and during the 1995 campaign, and it was the driving force behind the section's work in this regard. While I could not clearly identify a specific MaF strategy, it is worth highlighting its focus on influencing decision-making at the international level as well as its exchange with other IWN members, which contrasts with my observations about the Swiss section.

\subsubsection{Disinterest regarding women's rights}

Similar to the Swiss section, the membership of the German section showed no resistance to the initial work on women's rights, except for some critical voices who disapproved of the MaF's initial constitution and questioned the sense of its work. In a June 1986 article in the ai info, a member of the MaF wrote: "Meanwhile, some members expressed their concerns about our [group], which, in sum, question the sense, and the legitimacy of our [group] inside AI and our ability to positively influence and further develop AI's daily work." 297

In general, the issue of women's rights faced ignorance here, as well. However, as the following statement shows, the disinterest seems to have sometimes played an important role. In fact, according to an interviewee, those engaged in the promotion of women's rights issues within AI "sometimes had the impression of being forced to convince their own people of the necessity to work on women's rights much more than the public [...]." ${ }^{298}$ Generally, the critical voices against increasing the work on women's rights argued that

297 Amnesty International Sektion Bundesrepublik Deutschland: Artikel im ai info 6/86, Juni 1986, p.10: “In der Zwischenzeit haben einige Mitglieder Bedenken gegenüber unserem AK geäussert, die zusammengefasst den inhaltlichen Sinn, bzw. Die Existenzberechtigung unseres AK innerhalb ai's und unsere Möglichkeiten einer positiven Einflussnahme und Weiterentwicklung der alltäglichen ai-Arbeit in Frage stellen.". Ganzfried: Interview with B.T., 15.04.2015: "man [hatte teilweise] den Eindruck, man muss die eigenen Leute viel stärker noch von der Notwendigkeit der Arbeit zu Frauenrechten überzeugen als die Öffentlichkeit, [...]". 
"there are women's rights organizations, AI does not have to do this, it should better engage in the release of individual political prisoners." ${ }^{299}$

Instead, just like in the Swiss section, the most controversial discussion of the 1990s concerned the integration of states' responsibility for inaction in cases of grave human rights violations committed by non-state actors. According to an interviewee,

"the German section was almost divided on [the question of non-state actors]. [...] There were votes at the Ceneral Assemblies [...] battle votes and where we barely lost on the question 'Should Al become active in the case of persecutions by non-state actors and therewith in the case of gender-specific persecutions?"'300

While I could not find any evidence of specific opposition to engaging in the issue of FGM, the practice seemed to have been discussed as part of the larger debate about the mandate's enlargement to states' accountability for their inaction as a sort of "case study for the controversy." ${ }^{301}$ According to an interviewee, "the discussions were very theoretical. Theoretical in the sense of 'we want to have a coherent concept of our mandate." ${ }^{302}$ As the following statement shows, as in other sections, AI members feared that the organization would be overtaxed if it had to do research on cases of human rights violations committed by non-governmental entities:

"[...] the related concerns were just questions such as 'Al is not able to do research on all that.' And 'we are already at the limit of our ability to collect really solid information about human rights violations in the classical cases,

299 Ganzfried: Interview with B.T., 15.04.2015: "Es gibt ja Frauenorganisationen oder Frauenrechtsorganisationen und Amnesty soll sich doch lieber für den einzelnen politischen Cefangenen einsetzen, [...]".

300 Ganzfried: Interview by phone with B.E., 06.03.2015: "Also es gab SCHWIERICE Debatten, insbesondere in der deutschen Sektion. Also ich würde sagen, dass Anfang der goer die deutsche Sektion FAST gespalten war in dieser Frage. Also nicht sonst, aber halt in dieser Frage. Da gab es Abstimmungen auf der ] ahresversammlung [...] wo es wirklich KAMPFAbstimmungen gab und wir dann die Frage, SOLL Amnesty auch im Falle nichtstaatlicher Verfolgung UND damit geschlechtsspezifischer Verfolgung tätig werden "knapp verloren haben."

301 Ganzfried: Interview by phone with B.E., 06.03.2015.

302 Ganzfried: Interview by phone with B.E., 06.03.2015: "Die deutsche Sektion hat zum Teil sehr theoretisch diskutiert. Also theoretisch im Sinne von, Wir wollen ein stimmiges Konzept unseres Mandats haben.". 
such as torture, and then you are going to engage in the area of non-state actors where research is even more difficult!" ${ }^{303}$

Let me briefly summarize the main insights provided by the two case studies. Female activists initiated the work on issues of VAW by forming locally anchored Women Urgent Action Networks in the Swiss section and by establishing a section-wide "Arbeitskreis" focusing on the defense of women prisoners in the 1980s. In both sections, these women's groups remained the driving force behind the work on issues of VAW during the 1990s. However, the women at each section organized and proceeded differently. At the Swiss section, women had successfully established a women's network composed of five women's groups and a representative at the secretariat by the end of the 1990s. Thus, parallel networking seemed to have been a strategy female activists and officials used to make the section increase its activities on issues of VAW. Meanwhile, the female activists organized in the MaF focused on influencing decision-making at the international level and were in regular contact with the IWN. However, I could not find evidence for any clear strategy the MaF employed to make its section increase its work on issues of VAW.

Similar to the section's overall organization of its thematic work, the Swiss section professionalized the work on issues of VAW over the course of the Human Rights are Women's Rights campaign. Meanwhile, in the German section, the women's group continued to be responsible for the majority of the section's work on issues of VAW throughout the 1990s. In both sections, the membership's general reaction to AI's activities on issues of VAW and to the women's groups' demands to increase work on violations of women's rights was ignorance, rather than opposition. In contrast, the question of state responsibility for inaction in cases of grave human rights violations committed by non-state actors was an issue of major debate in both sections, just like it was at the international level.

303 Ganzfried: Interview by phone with B.E., 06.03.2015: "Also ja es war wirklich EXTREM umstritten. Und die Sorgen die damit verbunden waren, waren halt so Fragen wie, das kann Amnesty ja alles nicht recherchieren und, wir sind eh schon am Limit unserer Möglichkeiten wirklich SOLIDE Informationen über die Menschenrechtsverletzungen zu liefern in den KLASSISCHEN Fällen wie Folter und dann geht ihr jetzt in den nichtstaatlichen Bereich wo die Recherchen ja ungleich schwieriger sind".". 


\subsection{Intermediate conclusions}

Chapter 7 has illustrated the beginnings of Al's interest in VAW in detail. In the 1990s, AI's human rights policy gradually shifted away from its essential focus on civil and political rights, which saw the state as the primary violator of individuals' human rights. It moved towards adopting a mission that recognized the indivisibility of all human rights including economic, social and cultural rights in 2001 . The 1991 recognition that abuses committed by political non-state actors fell within the mandate was the first step of the subsequent redefinition of Al's policy. Later, AI decided to hold states accountable for inaction in cases of human rights violations committed by non-governmental entities, before it held private actors themselves responsible for abuses of human rights. In 2001, AI adopted the mission and expanded its policy to economic, social and cultural rights. These mandate developments were highly significant for effective action against VAW because they signified the end of the long-lasting public-private divide and allowed the organization to consider VAW as a consequence of structural inequalities rather than as individual acts. This, in turn, enabled AI to take action against VAW whoever the perpetrator. Concurrently with the modification of the mandate, AI adopted three consecutive ICM decisions calling on the movement to strengthen the work on women's rights for the first time.

The evolution of AI's policy on VAW was reflected in its activities. In fact, whereas AI's first comprehensive report on violations of women's rights, Women in the Front Line (1991), focused on gender-based violence in state custody and highlighted patterns of political persecutions of women, the 1995 Human Rights are Women's Rights campaign focused on torture, the death penalty, extra-judicial executions, and disappearances as they affected women. Nevertheless, the state remained the primary addressee of the organization's demands to prevent and condemn VAW. The Take a Step to Stamp Out Torture campaign launched in 2000 was seen as AI's first effective attempt to campaign against VAW in the private sphere because it independently considered all forms of VAW as acts of torture, whatever the context and whoever the perpetrator.

Women organizing and strategizing at the international and national levels are key to our understanding of AI's increasing interest in issues of VAW reflected in the above-mentioned policy developments and activities. Female activists, concerned about the under-representation of women in the cases defended by AI, not only initiated AI's work on issues of VAW by forming 
specific Urgent Action Networks and women's groups in the early 1980s. By forming the IWN and demanding an intensification of work on violations of women's rights within the frame of the mandate, rather than the abolition of the state-focused mandate, female activists and officials also successfully pressured AI to increase its work on VAW and to choose VAW in the private sphere as the theme of its first thematic long-term campaign under the mission. The external factors, such as the changing pattern of human rights violations (contributing to AI's questioning of its state-focused mandate), ${ }^{304}$ the growing international awareness of gender equality (especially in response to the conference in Beijing), ${ }^{305}$ the international women's rights movement (challenging AI to expand its mandate to violations of human rights in the private sphere), ${ }^{306}$ and some internal factors, such as SG Pierre Sanés positive stance and the growing number of women in AI's leadership positions, are therefore insufficient to fully explain the beginning of AI's work on issues of VAW and the movement's growing interest in issues of VAW in the 1990s. Instead, the latter must be seen primarily as the result of the feminist strategy of parallel networking and analogous framing.

In fact, by organizing in the IWN, female activists and officials were able to do effective internal lobbying for an increase in AI's work on violations of women's rights. Organizing in an intersectional network allowed the female activists and officials to reach out to the whole AI movement and build majorities for their demands at the ICMs. Further, female activists and officials called for an increase in AI's work on women's rights within the frame of the mandate. The strategy of analogous framing was crucial in making AI increase its work on VAW because it allowed garnering the majority of the movement's support for more seriously engaging in work on women's rights. In their quest, the fourth WCW in Beijing in 1995 appeared as an important window of opportunity, enabling women organized in the IWN and at the section level to enhance their lobbying efforts and make AI launch its first major theme campaign on women's rights. Finally, both of these strategies were important in making AI decide to launch its first long-term thematic campaign under the mission on the issue of VAW, as they enabled the effective lobbying of sections, the IEC, and the SG. They also convinced the organization of the necessity to further strengthen its work on violations of women's rights. 
AI's increasing interest in issues of VAW in the 1990s was accompanied by controversial internal discussions that crystallized in relevant ICM decisions, yet, above all, in AI's position on states' responsibility for inaction in cases of grave human rights violations. In this regard, the issue of how AI should proceed with the issue of FGM was discussed to much controversy at all levels of the movement during the 1990s. In contrast, the female activists' and officials' lobbying efforts and the multiplying activities on issues of VAW faced members' ignorance. Resistance could primarily be observed among IS staff who criticized the new focus and refused to incorporate a gender perspective into their work.

Thus, AI increasingly integrated VAW into its activities in the 1990s. The feminist strategies of parallel networking and analogous framing proved to be key to policy development and the implementation of activities on issues of VAW. They greatly contributed to making AI choose the issue of VAW in the private sphere as the theme of its first long-term global thematic campaign in 2001. In light of AI's historically grown, long-lasting gender-biased understanding of human rights, this decision was an important achievement. Yet were these achievements truly sustainable? Focusing on the period between 2001 and 2010, the following chapter intends to answer this question. 